Proc. Estonian Acad. Sci. Geol., 2001, 50, 4, 254-281

\title{
PODZOLIZATION IN AEOLIAN SANDS, UNDERLAIN BY GLEYSOL FORMATION, DURING NINE MILLENNIA IN SOUTHWESTERN ESTONIA
}

\author{
Loit REINTAM ${ }^{\mathrm{a}}$, Anto RAUKAS ${ }^{\mathrm{b}}$, Anne KLEESMENT $^{\mathrm{b}}$, Tanel MOORA $^{\mathrm{c}}$, \\ and Raja KÄHRIK ${ }^{\mathrm{a}}$
}

a Institute of Soil Science \& Agrochemistry, Estonian Agricultural University, Viljandi mnt., Eerika, 51014 Tartu, Estonia; loit@eau.ee

b Institute of Geology, Tallinn Technical University, Estonia pst. 7, 10143 Tallinn, Estonia; raukas@gi.ee

${ }^{c}$ Institute of History, Rüütli 6, 10130 Tallinn, Estonia

Received 8 August 2001, in revised form 27 August 2001

Abstract. An outcrop of Carbic Podzol on aeolian sand, underlain by Molli-Histic Gleysol on calcareous till of the last glaciation, was studied on the bank of the Lemmejõgi River, SW Estonia. Molli-Histic Gleysol at depths of $342-380 \mathrm{~cm}$ formed as a result of pedogenesis within the Younger Dryas-Pre-Boreal during about 1500-3200 years at an average accumulation rate of organic carbon of 5.3-2.5 $\mathrm{g} \mathrm{m}^{-2} \mathrm{yr}^{-1}$. The histic horizon formed during about 1000 years at a rate of $12-13 \mathrm{~g} \mathrm{~m}^{-2} \mathrm{yr}^{-1}$ of organic carbon. Gleying of underlying till has led to slight textural changes but to some essential changes in mineral and chemical status. Gleysol was buried under the sediments of the Ancylus transgression about 9200-9000 years ago. Within the uppermost stratum, stratified sands have been reshaped by coastal winds after the retreat of the shoreline. Simultaneously with the development of the forest vegetation, pedogenesis started a little later than $9000 \mathrm{BP}$, and a unitary Carbic Podzol with the A-E-Bhs-Bs-BC-C sequence was formed. Organic C has accumulated at an average rate of $8.1 \mathrm{mg} \mathrm{m}^{-2} \mathrm{yr}^{-1} \mathrm{~cm}^{-1}$ in the A-E-Bhs sequence, while the $\mathrm{A}$ - and Bhs-horizons were humus-accumulative and humus-illuvial in origin, respectively. Under the influence of $\mathrm{R}_{2} \mathrm{O}_{3^{-}}$and/or Ca-fulvic humus, total cheluviation and formation of the albic horizon has proceeded at a rate of $55 \mu \mathrm{m} \mathrm{yr}^{-1}$. The solum of $180 \mathrm{~cm}$, formed during about 9000 years, represents the result of the weathering and podzolization of the initial sand column of $171 \mathrm{~cm}$, while the upward expansion in the uppermost $75 \mathrm{~cm}$ progressed at a rate of $6-7 \mu \mathrm{m} \mathrm{m}^{-2} \mathrm{yr}^{-1}$. As a consequence of interfraction changes, $5.6 \mathrm{~g} \mathrm{~m}^{-2} \mathrm{yr}^{-1}$ of fine particles and $2.9 \mathrm{~g} \mathrm{~m}^{-2} \mathrm{yr}^{-1}$ of chemical constituents have accumulated in the solum, although the A-E sequence is eluvial. Quartz and feldspars have mostly concentrated in fine sand. The increase in ore minerals and/or their eluvio-illuvial distribution has been induced by the weathering of pyroxenes and amphiboles. Against the background of total accumulativeness, the relationships of nonsiliceous substances are characterized by podzolic distribution. Due to human and some evident natural agents, a decrease in acidity and an increase in base exchange capacity and base saturation have taken place in the A-E-Bhs sequence of Carbic Podzol.

Key words: aeolian sands, Holocene pedogenesis, podzolization, Carbic Podzol, soil composition, soil properties, changes in pools. 


\section{INTRODUCTION}

Since V. V. Dokuchaev (1846-1903), podzolization has deserved the wide attention of researchers of pedogenesis in forest areas (Rode 1937; Muir 1961; Ponomareva 1964; Mokma \& Buurman 1982; van Breemen \& Buurman 1998; Lundström et al. 2000a). By Rode (1937), podzolization represents the breakdown of both primary and secondary minerals as well as the downward removal and translocation of products in the form of elementary compounds and/or chelatic organo-metallic complexes. This results in the formation of both albic and spodic horizons (FAO/ISRIC 1998), while the spodic one appears to be of primary importance for diagnostics everywhere. The process is evident in the presence of aggressive fulvic humus and organic acids in sandy parent material, poor in alumosilicates and bases of any origin (Lundström et al. 2000b). The percolative water regime is also obligatory.

Studying the rate of soil formation, Katchinskaja (1937) suggested the expression of podzolic attributes already within twelve years. The beach-ridge sequence in Northern Michigan demonstrated clear patterns of early soil podzolization within 400 years (Lichter 1998). Podzols on different sandy deposits have been described from tundra to tropics, except for polar regions, while in many cases their age can attain several millennia (Mokma \& Buurman 1982). Besides Rendzic Leptosols on limestone and Gleysols in the conditions of the aquic regime, podzolization and sandy Podzols represent soil phenomena that could have developed at any stage of pedogenesis during the Pre-Pleistocene and since the Late Pleistocene within the entire Holocene in Estonia (Reintam 1997a).

This paper focuses on the development, speed, and rate of the temporally uninterrupted progress of podzolization in Ancylus Lake and aeolian sands, underlain by the Younger Dryas and Pre-Boreal Molli-Histic Gleysol on calcareous reddish-brown till at a depth of about $3.4 \mathrm{~m}$. Within their upper two metres, slightly stratified sands appear to be reblown by coastal winds immediately after the retreat of Ancylus Lake from the area. The presence of Podzol without any (sub)sections of different age was noted also by the participants of the Baltic traverse tour of the INQUA XIV International Congress in 1995.

\section{MATERIAL AND METHODS Site, topography, geology, and sampling}

An outcrop of the Podzol/Gleysol profile was described and sampled on the left bank of the Lemmejõgi River $\left(57^{\circ} 58^{\prime} \mathrm{N}, 24^{\circ} 25^{\prime} \mathrm{E}\right)$ at a distance of $350 \mathrm{~m}$ from the mouth of the river (Fig. 1). The Lemmejõgi (also Orajõgi) begins in the Nigula Bog and enters into the Gulf of Riga south of the village of Kabli. Its length is $23 \mathrm{~km}$ and catchment area $57 \mathrm{~km}^{2}$. The Eifelian sandstone of the Middle Devonian Aruküla Regional Stage, covered with a thin layer of the reddishbrown till of the last glaciation, crops out near the mouth of the river. Buried 


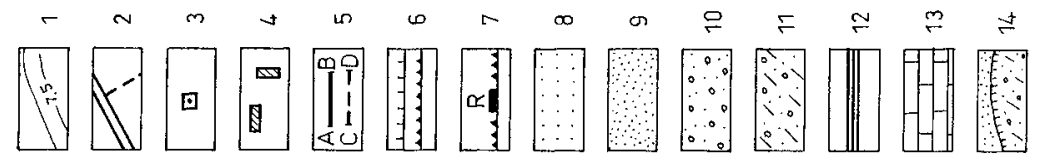

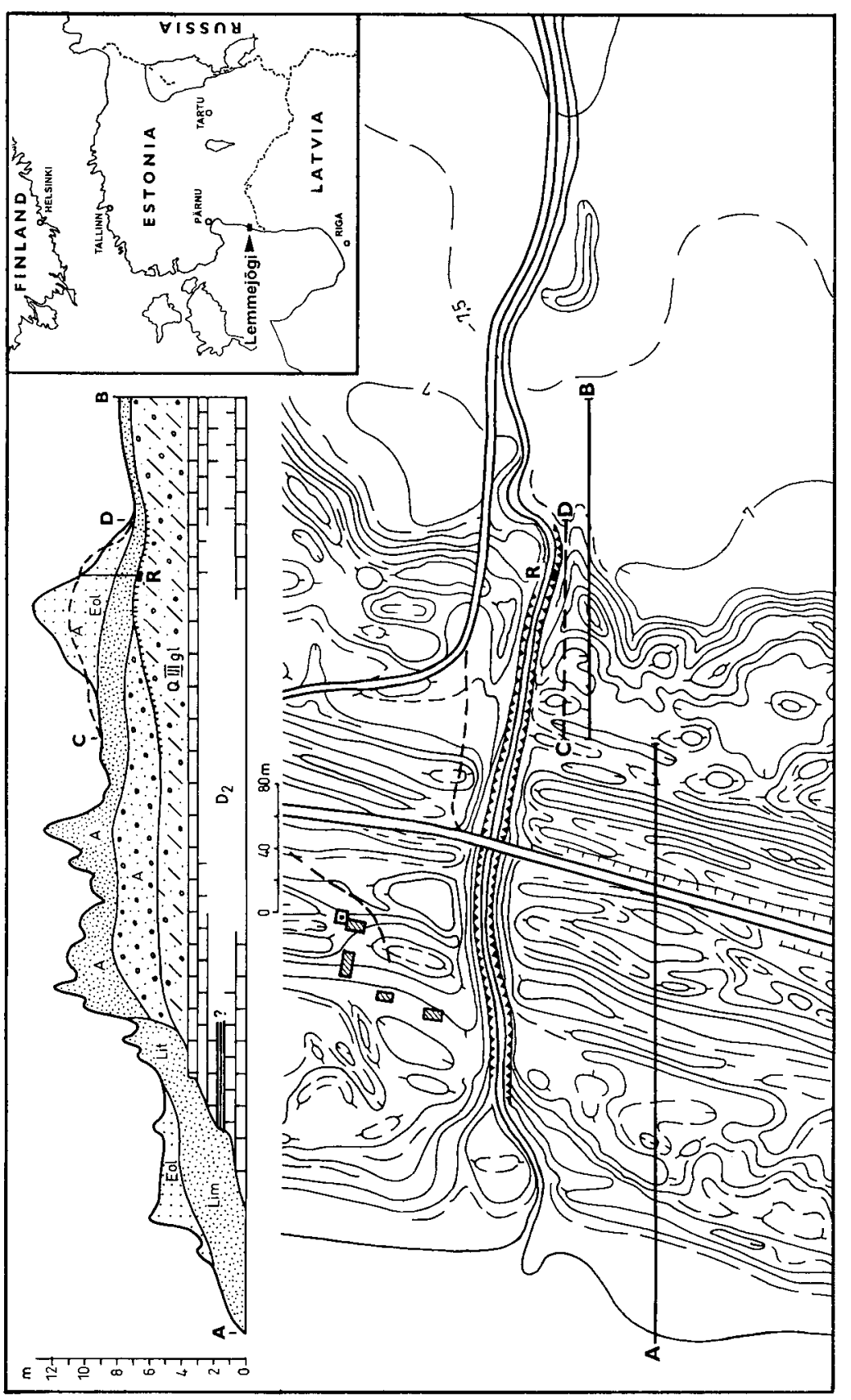

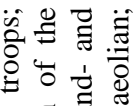

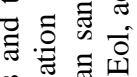

卷

단

तै

远范

总远焉

己

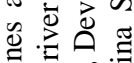

응

$\therefore$ 을

$\infty:=$

《司茂

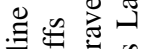

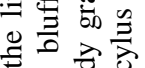

跼焉完

하워

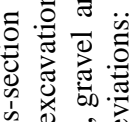

过 000

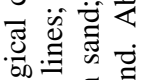

드응

跑

चี

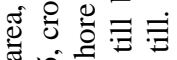

的部

प.

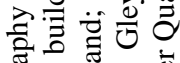

昰市

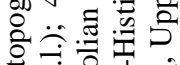

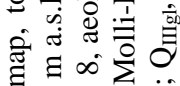

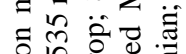

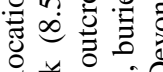

普政

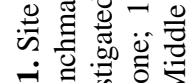

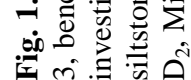


Molli-Histic Gleysol, formed on rather thin $(2-3 \mathrm{~m})$ till during the Yoldia Sea regression at the beginning of the Holocene, occurs within a stretch of $50 \mathrm{~m}$ on both banks. The buried molli-histic horizon has been repeatedly studied and dated (Kessel \& Raukas 1967; Raukas \& Hyvärinen 1992). The following results have been obtained: $9100 \pm 85$ (TA-123), 9240 \pm 85 (TA-122), 9820 \pm 130 (Tln-130), $9440 \pm 100$ (Hel-2208A), and 9430 \pm 100 (Hel-2208B). In the last two cases, the first date was obtained from the bulk sample and the second, from extracted humus from the same sample. Within about $20 \mathrm{~m}$ of the site, the following new data of ${ }^{14} \mathrm{C}$ age were obtained: $9162 \pm 84$ (Tln-2564) and $9503 \pm 82$ (Tln-2589) for the alkaline insoluble fraction and 9094 $\pm 61(T \ln -2572)$ and 9396 $\pm 75(T \ln -2590)$ for the soluble fraction of the lowermost part of the AH-horizon. All radiocarbon dates referred to in the text are uncalibrated radiocarbon years before present (BP). Also, all geological events and time intervals are given in uncalibrated ${ }^{14} \mathrm{C}$ years BP. According to the obtained ${ }^{14} \mathrm{C}$ dates, the Ancylus transgression started some $9500 \mathrm{BP}$ and culminated in the Lemmejõgi area about 9200-9000 BP (Raukas et al. 1995b).

The hilly aeolian topography, extending from the sea in the west to the till plain in the east, is some $450 \mathrm{~m}$ wide. In the narrow, meridionally elongated strip, dune sands of the Ancylus, Litorina, and Limnea stages are overlapping (Fig. 1). However, it seems that the dunes of Limnea age are situated mainly to the west of the old Heinaste-Häädemeeste highway, some hundred metres away from the site. There is no distinct boundary between the Ancylus and Litorina dune sands. Most probably, the dunes of Litorina age are, at least locally, overlying the dunes of Ancylus age. Aeolian sand has been derived from the local source material of Ancylus origin and dunes started to develop here immediately after source deposits on the shore became available. The process stopped when the dunes were overgrown with the forest vegetation. As the Litorina transgression in the Lemmejõgi area was not extensive, pine stands (Pinus sylvestris) with birch (Betula pendula) and some ground vegetation, characteristic of the stage between the Ancylus regression and the subsequent slow Litorina transgression (Thomson 1929) about 7000-6000 BP, must have developed here since the Ancylus regression, which culminated between $8500-8000$ BP. For calculations we took 9000 years for pedogenesis, because the formation of beach sediments and their aeolian redeposition could most probably have started here already at that time. Podzol in the Lemmejõgi area displays no signs of fire.

The soil and sediment sequence of the outcrop, described in 1999, has the following main characteristics (Table 1). The profile of Carbic Podzol, underlain by Molli-Histic Gleysol, stretches to a depth of $180 \mathrm{~cm}$, while the solum within $100-180 \mathrm{~cm}$ is slightly striped (Fig. 2). Striping appears to be sedimentary in origin, but earlier pedogenetic phenomena cannot be excluded either, as it has been described from France (Fichter et al. 1998) and Belarus (Smeyan et al. 2000). The pedogenetically unaffected yellow sand is stratified and represents parent 
Table 1. General characterization of the outcrop

\begin{tabular}{|c|c|c|c|c|c|c|c|}
\hline \multirow[t]{2}{*}{ Material } & \multirow{2}{*}{$\begin{array}{l}\text { Horizon and } \\
\text { depth, cm }\end{array}$} & \multirow[t]{2}{*}{ Colour } & \multirow[t]{2}{*}{ Characteristics } & \multirow{2}{*}{\begin{tabular}{|c|} 
Thick- \\
ness, $\mathrm{cm}$
\end{tabular}} & \multicolumn{3}{|c|}{ Weight, $\mathrm{kg} \mathrm{m}^{-2}$} \\
\hline & & & & & Soil & Parent sand & Changes, \pm \\
\hline Reblown & А $0-10$ & 10YR5/1 & Ochric, weak & 10 & 137 & 151 & -14 \\
\hline Ancylus & A $10-24$ & & rooted & 14 & 199 & 211 & -12 \\
\hline beach & Е 24-50 & $10 \mathrm{YR} 7 / 2$ & Albic & 26 & 377 & 393 & -16 \\
\hline \multirow[t]{6}{*}{ sand } & Bhs $50-75 b^{*}$ & $5 \mathrm{YR} 3 / 4$ & Spodic, brown & 13 & 189 & 196 & -7 \\
\hline & Bhs $50-75 y^{*}$ & 7.5YR4/6 & Spodic, yellow & 12 & 168 & 181 & -13 \\
\hline & Bs $75-100$ & 7.5YR4/6 & & 25 & 370 & 378 & -8 \\
\hline & BC 100-180 & 10YR6/8 & Striped & 80 & 1192 & 1208 & -16 \\
\hline & Total 0-180 & & & 180 & 2632 & 2718 & -86 \\
\hline & C 180-306 & 10YR6/3 & Stratified & 10 & & 151 & \\
\hline $\begin{array}{l}\text { Ancylus } \\
\text { beach sand }\end{array}$ & A $306-342$ & & Slightly humous & 36 & 454 & $\begin{array}{c}126 \\
(10 \mathrm{~cm})\end{array}$ & \\
\hline Yoldian & AH 342-351 & 7.5YR1.7/1 & Molli-histic & 9 & 28.8 & & \\
\hline soil & AH 351-360 & & Histi-mollic & 9 & 83.7 & & \\
\hline \multirow[t]{2}{*}{ Till } & IIG 360-370 & 10G5/1 & Gleyic & 10 & 181 & & \\
\hline & IICg 370-380 & $5 Y R 5 / 2$ & Gleyed & 10 & 194 & & \\
\hline
\end{tabular}

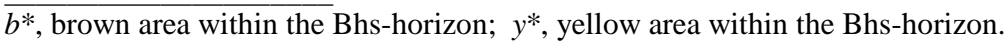

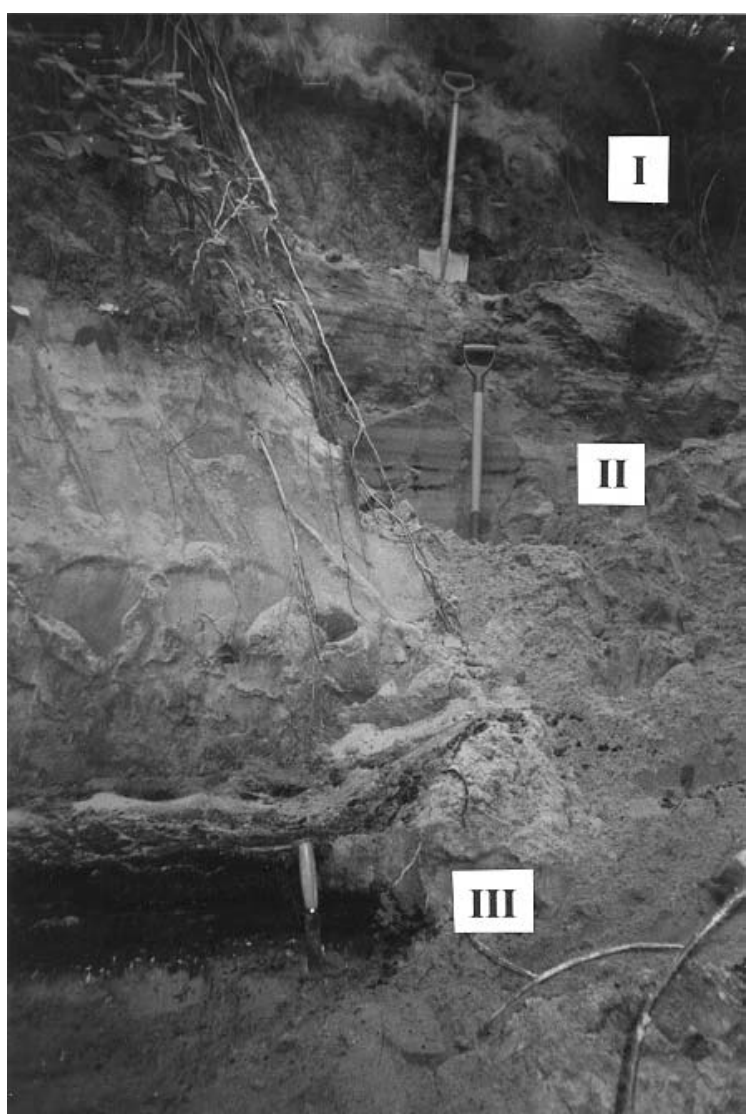

Fig. 2. Soils and the sediment sequence of the Lemmejõgi outcrop: Carbic Podzol (I), striped sand (II), and Molli-Histic Gleysol (III). Photo by L. Reintam. 
Fig. 3. The A-E-Bhs-Bs-BC-C sequence of Carbic Podzol with a total solum thickness of $180 \mathrm{~cm}$ at the top of the Lemmejõgi outcrop. Photo by L. Reintam.

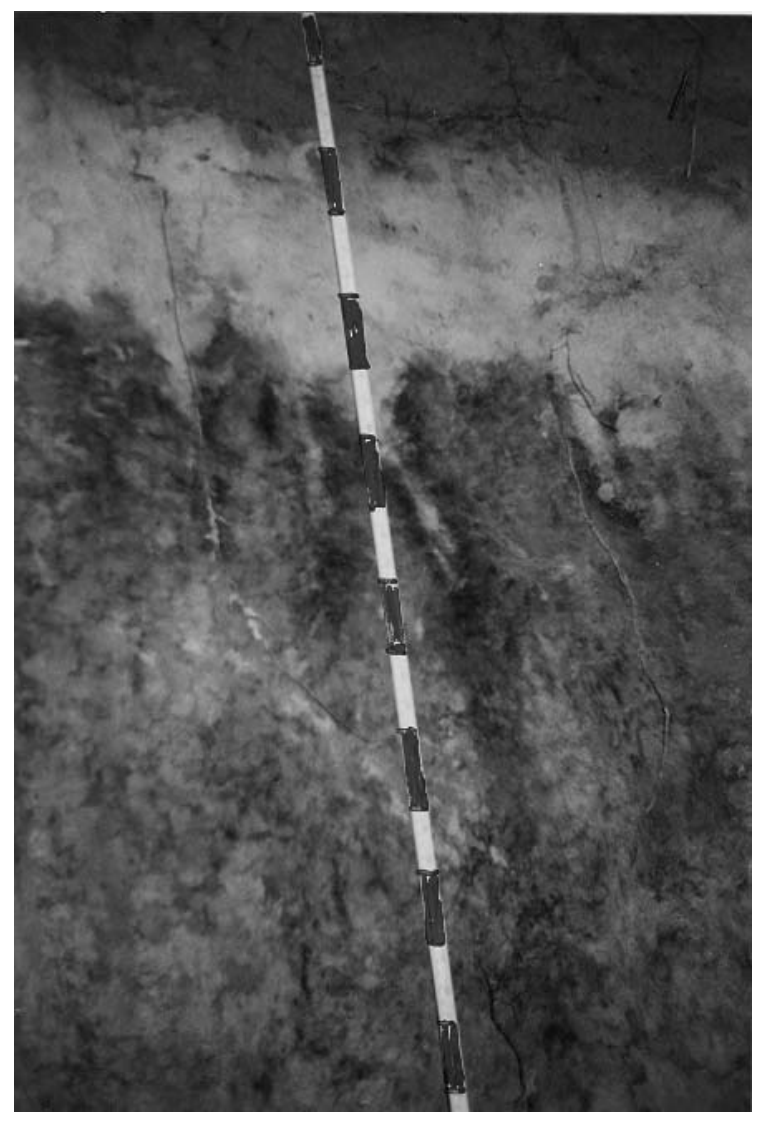

material for soil formation. This demonstrates the initially aqueous origin of sand whose striping and/or stratification have disappeared as a result of aeolian activity prior to pedogenesis and podzolization. The unitary podzol section without any subsection can be followed in the entire outcrop (Fig. 2) as well as in its top (Fig. 3). No podzolization can be observed above the underlying Gleysol section, although there occurs a slight accumulation of humus (Fig. 4).

The morphological description and soil sampling by genetic horizons, their parts, and parent materials were carried out to a depth of $380 \mathrm{~cm}$ using the methods well known in soil science. By the way, in the spodic Bhs-horizon, two samples were taken from the same depth $(50-75 \mathrm{~cm})$ : from the brown, very compact and dark area ( $b$ in tables) and from the yellow ( $y$ in tables), more mellow light area (Fig. 3). Each area formed about 50\% of the entire horizon. Bulk density of all horizons and subhorizons was determined in four replications using a steel cylinder of $50 \mathrm{~cm}^{3}$. All samples were completed as an average of different parts of the respective horizon and/or sand layer. 


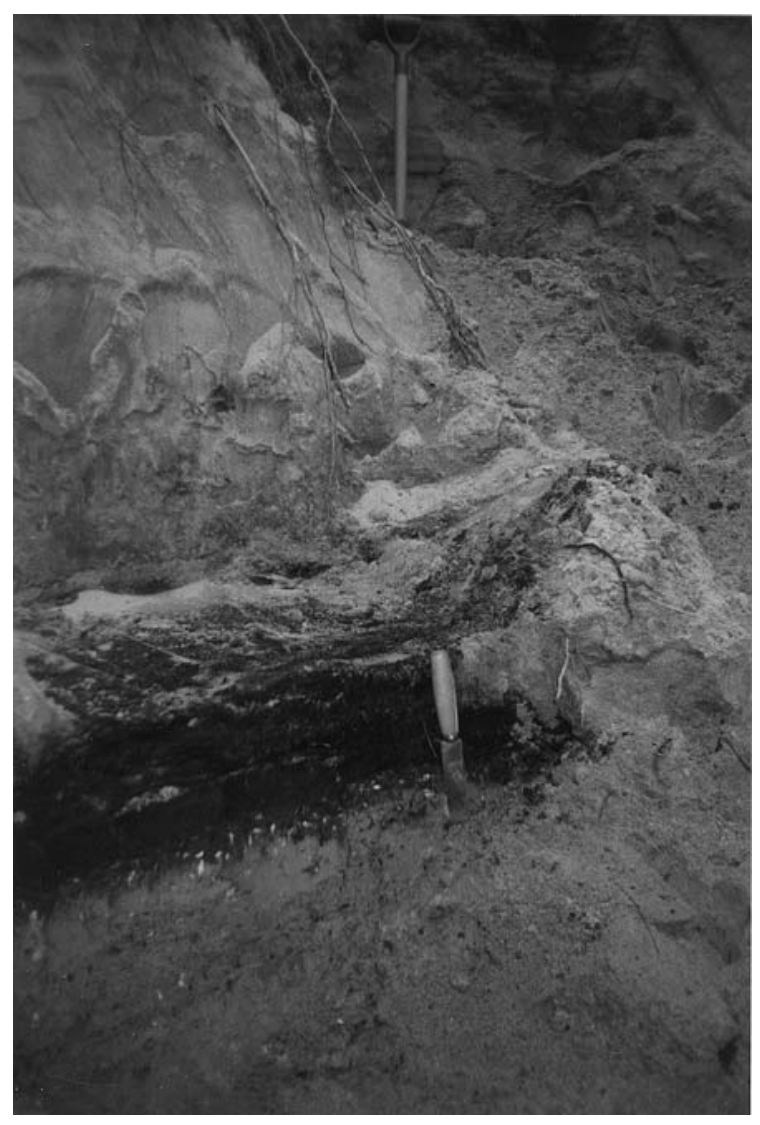

Fig. 4. The AH-G-Cg sequence of Molli-Histic Gleysol at the bottom of the Lemmejõgi outcrop. Photo by L. Reintam.

\section{Analyses}

Chemical analyses of soil were performed in the laboratories of the Institute of Soil Science \& Agrochemistry, Estonian Agricultural University. Fine earth with particle size less than $2 \mathrm{~mm}$ was used. Samples for the determination of particle size were treated with sodium pyrophosphate to break down aggregates. Sands were sieved and fractions finer than $0.05 \mathrm{~mm}$ were determined by pipette analysis (Pipette Apparatus Table Model 7 Samples). Total chemical analysis was carried out after alkaline fusion treatment. Iron and aluminium were ascertained by means of sulphosalicylic acid and aluminone, respectively; alkaline earths, potassium, and sodium were determined by flame photometry. Carbonates were determined acidometrically for recalculation of measurement data. The obtained results were expressed for ignited noncalcareous material (Arinushkina 1970; van Ranst et al. 1999). The reliability of these techniques was repeatedly verified by atomic absorption spectrometry. 
The group and fractional composition of humus was determined by alternate acid-alkaline treatment using the Tyurin-Ponomareva volumetric method (Ponomareva 1957). The results were expressed in the percentages of organic carbon. Total amounts of organic carbon and nitrogen were ascertained by the Tyurin and Kjeldahl methods, respectively. It is necessary to point out that the Anne method known in Western countries (van Ranst et al. 1999) is equivalent to the Tyurin method used. Tithionite-extractable (total nonsiliceous) iron, oxalate-extractable amorphous iron, aluminium, and silica were measured after Coffin and Tamm, respectively; iron activity was calculated after Schwertmann (van Ranst et al. 1999). Base exchange capacity (BEC) and exchangeable bases were measured by percolation of the samples with ammonium acetate at $\mathrm{pH} 7.0$ and expressed in $\mathrm{cmol} \mathrm{kg}^{-1}$. The $\mathrm{pH}$ of both water and $1 \mathrm{M} \mathrm{KCl}$ suspensions was measured potentiometrically with the $\mathrm{pH}$-meter Jenway 3071. Exchange acidity $\left(\mathrm{H}^{+}+\mathrm{Al}^{3+}\right)$ was ascertained after Daikuhara-Sokolov in $1 \mathrm{M} \mathrm{KCl}$. Specific surface area was measured after Puri and Murari using water absorption from the steamsaturated atmosphere above $41 \%$ sulphuric acid (Kitse \& Rooma 1984). The obtained results were expressed in $\mathrm{m}^{2} \mathrm{~g}^{-1}$. The soils were termed in accordance with World Reference Base for Soil Resources (FAO/ISRIC 1998).

For mineral analysis, fractions of $0.5-0.25,0.25-0.1$, and $0.1-0.05 \mathrm{~mm}$ were separated by wet sieving. Dry samples were analysed at the Institute of Geology at Tallinn Technical University. Using the immersion method, light $\left(\mathrm{SG}<2.89 \mathrm{Mg} \mathrm{m}^{-3}\right.$ ) and heavy ( $\mathrm{SG}>2.89 \mathrm{Mg} \mathrm{m}^{-3}$ ) mineral suites from all grainsize fractions were separated. Altogether 200-500 mineral grains were counted in each mineral suite and the results were expressed in the percentages of the respective fraction. The degree of quartz rounding was determined using a 6-step scale on which 0.3 is subangular and 0.4 is subrounded (Scholle 1979).

The quantitative origin of Holocene and current changes was established by the material balance method (Targulian et al. 1974; Rozanov 1975; Reintam 1985, 1990). On the basis of the equations and calculations presented by Brimhall \& Dietrich (1987), a similar method is recommended by van Breemen \& Buurman (1998). The weight of the soil horizons and their textural and chemical constituents as of 1999 were compared with those recorded for initial sand at depths of 250-260 cm. According to Targulian et al. (1974) and Rozanov (1975), the fractions of sand $>0.05 \mathrm{~mm}$ were regarded as an indicator of the initial status prior to pedogenesis. Changes in the thickness (depth) of the initial column of soil horizons with an area of one square metre were calculated on the basis of the measurement data by the formula published elsewhere (Targulian et al. 1974; Rozanov 1975; Reintam 1997b). Depending on changes in bulk density, loosening of the soil and the upward growth of the horizon (profile) were taken into account. 


\section{RESULTS AND DISCUSSION \\ Formation and status of organic matter}

The retreat of the Fennoscandian ice-sheet some 12500 BP opened Southwest Estonia for the formation of the plant cover and synchronous development of pedogenesis. Prior to this study, ancient soil sections on till beneath Holocene and/or Upper Pleistocene sediments had not been described. In the figures presented by Kessel (1963) for Southwest Estonian sites, obvious buried soil formations are qualified as "organic sediments". The occurrence of rewashed grey loamy calcareous till under buried peat at Lõpe, SW Estonia, was later mentioned by Raukas et al. (1995a), but also without a pedological interpretation. The section in the lowermost part of the Lemmejõgi outcrop appears to be the first that was sampled directly from the top of strongly gleyed till (Table 1, Figs. 2 and 4). The lack of aqueous sediments between the histic epipedon and till shows that the Molli-Histic Gleysol opened represents the result of the paludification of dry land. As varved clays and/or any other aqueous deposit are absent, the organic-mineral interactions and soil formation appear to have lasted about 3200 years in the places where till "islands" were free from water. If we suppose that meltwater of the Baltic Ice Lake covered the entire Lower Estonia, but with no sediments on the microhillocks of the underlying till, the duration of pedogenesis should be at least about 1500 years: from the subarctic Younger Dryas to the cool and moist Pre-Boreal (10 000-9000 BP). Gelic Regosol must have formed prior to its possible evolution into automorphic Calcaric Regosol under pine (described by rich pollen) and further into Gleyic Regosol and Gleysol under the increasing influence of gleying in the transition from the Younger Dryas to the Pre-Boreal. Rapid increase in the pollen of herbs appears to be accompanied with the decrease in the importance of pine under the waterlogging. Sudden beginning and progress of the aquic regime is dated at $9503 \pm 82 \mathrm{BP}(\mathrm{T} \ln -2589)$ for the insoluble fraction, from where fungi and mycobacteria had already disappeared, and at $9396 \pm 75 \mathrm{BP}$ (Tln-2590) for soluble humus substances. Radiocarbon data confirms the rapid progress of mollic and histic properties within the Yoldia Sea Stage 10 300-9300 BP (Raukas \& Hyvärinen 1992). This resulted in the formation of the histic horizon during about one millennium. The average annual increment in organic $\mathrm{C}$ is $12-13 \mathrm{~g} \mathrm{~m}^{-2} \mathrm{yr}^{-1}$ in the layer of $18 \mathrm{~cm}$, being about twice higher in the lower part than in the upper one. Supposing that some organic carbon accumulated, at least in the lower section of the molli-histic horizon, during about 3200 years, the average annual increment should have been about $2.5 \mathrm{~g} \mathrm{~m}^{-2} \mathrm{yr}^{-1}$. The average annual increment of organic carbon appears to be more than twice higher $\left(5.3 \mathrm{~g} \mathrm{~m}^{-2} \mathrm{yr}^{-1}\right)$ in the totally flooded area. The $\mathrm{R}_{2} \mathrm{O}_{3}$-humic humus, saturated with alkaline earths, occurs in the epipedon of pedogenesis within the PreAncylus stages, the degree of humification being $170-230 \mathrm{~g} \mathrm{~kg}^{-1}$ in the histic formations. This situation is similar to that in Mollic and Histic Gleysols of any age (Reintam \& Moora 1998). 
Table 2. Composition of humus in percentages of organic carbon

\begin{tabular}{|c|c|c|c|c|c|c|c|}
\hline \multirow[t]{2}{*}{ Characteristics } & \multicolumn{7}{|c|}{ Horizon and depth, $\mathrm{cm}$} \\
\hline & $\begin{array}{c}\mathrm{A} \\
0-10 \\
\end{array}$ & $\begin{array}{c}\text { A } \\
10-24\end{array}$ & $\begin{array}{c}\mathrm{E} \\
24-50 \\
\end{array}$ & $\begin{array}{c}\text { Bhs } \\
50-75 b^{*}\end{array}$ & $\begin{array}{c}\text { Bhs } \\
50-75 y^{*}\end{array}$ & AH $342-351$ & AH $351-360$ \\
\hline Organic carbon, $\mathrm{g} \mathrm{kg}^{-1}$ & 5.0 & 7.5 & 1.7 & 8.5 & 6.0 & 147.6 & 96.6 \\
\hline Carbon pool, $\mathrm{g} \mathrm{m}^{-2}$ & 685 & 1492 & 641 & 1607 & 1008 & 4251 & 8085 \\
\hline Total nitrogen, $\mathrm{g} \mathrm{kg}^{-1}$ & 0.3 & 0.5 & 0.1 & 0.2 & 0.2 & 5.0 & 4.3 \\
\hline Nitrogen pool, $\mathrm{g} \mathrm{m}^{-2}$ & 41 & 100 & 38 & 38 & 34 & 144 & 360 \\
\hline $\mathrm{C}: \mathrm{N}$ & 16.7 & 15.0 & 17.0 & 42.5 & 30.0 & 29.5 & 22.5 \\
\hline \multicolumn{8}{|l|}{ Humic acids } \\
\hline 1 & 28.0 & 29.3 & 11.8 & 8.2 & 6.7 & 5.6 & 9.6 \\
\hline 2 & 0.0 & 0.0 & 0.0 & 0.0 & 0.0 & 0.0 & 9.3 \\
\hline 3 & 6.0 & 6.7 & 5.9 & 2.4 & 1.7 & 7.6 & 4.8 \\
\hline Total & 34.0 & 36.0 & 17.7 & 10.6 & 8.4 & 13.2 & 23.7 \\
\hline \multicolumn{8}{|l|}{ Fulvic acids } \\
\hline $1 \mathrm{a}$ & 6.0 & 1.3 & 0.0 & 25.9 & 30.0 & 0.3 & 0.6 \\
\hline 1 & 30.0 & 13.3 & 0.0 & 24.7 & 3.3 & 4.7 & 6.0 \\
\hline 2 & 22.0 & 22.7 & 41.2 & 7.1 & 23.3 & 3.2 & 4.6 \\
\hline 3 & 2.0 & 2.7 & 0.0 & 0.0 & 0.0 & 2.9 & 2.7 \\
\hline Total & 60.0 & 40.0 & 41.2 & 57.7 & 56.6 & 11.1 & 13.9 \\
\hline $0.5 \mathrm{M} \mathrm{H}_{2} \mathrm{SO}_{4}$ hydrolysate & 2.0 & 2.7 & 5.9 & 2.4 & 3.3 & 3.9 & 4.1 \\
\hline Total soluble & 96.0 & 78.7 & 64.8 & 70.7 & 68.3 & 28.2 & 41.7 \\
\hline Insoluble & 4.0 & 21.3 & 35.2 & 29.3 & 31.7 & 71.8 & 58.3 \\
\hline Humic acids : fulvic acids & 0.57 & 0.90 & 0.43 & 0.18 & 0.15 & 1.19 & 1.71 \\
\hline 1 st fr. : 2nd fr. & 2.64 & 1.88 & 0.29 & 4.63 & 0.43 & 3.22 & 1.12 \\
\hline \multicolumn{8}{|l|}{ Decalcinate, $\mathrm{g} \mathrm{kg}^{-1}$} \\
\hline $\mathrm{Fe}$ & 0.3 & 0.1 & 0.0 & 0.7 & 0.5 & 1.7 & 15.5 \\
\hline $\mathrm{Al}$ & 0.8 & 0.3 & 0.1 & 3.6 & 4.8 & 1.9 & \\
\hline $\mathrm{Ca}$ & 0.9 & 1.0 & 0.2 & 0.4 & 0.3 & 11.1 & 9.2 \\
\hline $\mathrm{Mg}$ & 0.6 & 0.8 & 0.5 & 0.8 & 0.7 & 4.9 & 5.4 \\
\hline
\end{tabular}

$b^{*}$, brown area within the Bhs-horizon; $y^{*}$, yellow area within the Bhs-horizon.

As a result of the Ancylus transgression, the Molli-Histic Gleysol formed was buried under sand. The presence of a layer with the organic carbon content of $2.9 \mathrm{~g} \mathrm{~kg}^{-1}$ and nitrogen content of $0.2 \mathrm{~g} \mathrm{~kg}^{-1}$ at depths of $306-342 \mathrm{~cm}$ above the histic epipedon of Gleysol appears to demonstrate either a temporary break in flooding, allowing of the development of a terrestrial vegetation, or the occurrence of an aqueous vegetation in floods, which induced a slight accumulation of humus substances in this layer. More recent illuviation and/or lateral translocation of humus can be excluded due to the structure and composition of the outcrop as well as humus maturity $(\mathrm{C}: \mathrm{N}=14.5)$. Further, there accumulated aqueous sands with an aeolian transformation in their top (Table 1). Only the about $75-\mathrm{cm}$ top was affected by active pedogenetic changes. Carbic Podzol shows the eluvio-illuvial podzolic distribution of organic constituents (Table 2). On average, $0.604 \mathrm{~g} \mathrm{~m}^{-2} \mathrm{yr}^{-1}$ of organic carbon has accumulated there: $0.242,0.071$, and 
$0.291 \mathrm{~g} \mathrm{~m}^{-2} \mathrm{yr}^{-1}$ in the A-, E-, and Bhs-horizons, respectively. In the lowermost Bs- and BC-horizons, the content of organic carbon is $1.6-4.8 \mathrm{~g} \mathrm{~kg}^{-1}$, while the average annual formation of its pool $\left(0.702 \mathrm{~g} \mathrm{~m}^{-2} \mathrm{yr}^{-1}\right)$ is distributed across a layer of $105 \mathrm{~cm}$. For the sequences A-E-Bhs and Bs-BC, annual accumulation was 8.1 and $6.7 \mathrm{mg} \mathrm{m}^{-2} \mathrm{yr}^{-1} \mathrm{~cm}^{-1}$, respectively. The process was especially intensive $\left(11.6 \mathrm{mg} \mathrm{m}^{-2} \mathrm{yr}^{-1}\right)$ per centimetre in the spodic horizon and only a little slower $\left(10.1 \mathrm{mg} \mathrm{m}^{-2} \mathrm{yr}^{-1} \mathrm{~cm}^{-1}\right)$ in the ochric epipedon. The albic horizon is poor in organic carbon $\left(2.7 \mathrm{mg} \mathrm{m}^{-2} \mathrm{yr}^{-1} \mathrm{~cm}^{-1}\right)$, because the chelates formed there are translocated into the spodic horizon. Similar regularities are observed in nitrogen in Podzol formed on sands within about 9000 years (Table 2).

The brown area of the spodic horizon is characterized by $\mathrm{R}_{2} \mathrm{O}_{3}$-fulvic humus (Table 2). Due to the large proportion of Ca-fulvates, humus is Ca-fulvic in the albic horizon as well as in the yellow area of the spodic horizon. Such a situation is common in podzolic sections, where total humousness is very low and stable humic-fulvic complexes are lacking altogether (Ponomareva 1964). It is evident that total fulvicity could have been higher during the earlier stages of pedogenesis, especially within the moist and warm Atlantic period (8000-5000 BP) when podzolization in sands must have been favoured. However, constant deficit of aggressive fulvic acids cannot be excluded in the interpretation of the slow progress of podzolization in depth, either. By the scenario to climate change effects (Borken et al. 1999) alternating draughts and rewettings in the past and contemporary aridity due to well-developed natural drainage have probably had an impact on the status of humus. According to Rode (1937), a slight accumulation of soluble humus took place in the early phase of podzolization in dry sands everywhere. It means that the formation of the contemporary A-horizon began already within the early Litorina Sea Stage (some 8000-6500 BP) and has continued slowly up to the present simultaneously with the appearance and development of albic properties and progress of an independent albic horizon in depth. Therefore the ochric epipedon with a very low content of organic carbon is eluvial in origin, and the annual increase in total cheluviation in depth is about $55 \mu \mathrm{m} \mathrm{yr}^{-1}$. Against this background, the average annual increase in the thickness of the albic horizon reached $29 \mu \mathrm{m} \mathrm{yr}^{-1}$. The spodic horizon had increased to nearly the same extent. As Brahy et al. (2000) suggested for surface podzolization, the extent of the migration of metal-organic complexes in depth as well as of the progress of the podzolic profile has probably been a few centimetres. According to Stützer (1998), fulvic humus is not the only factor determining podzolization here; the process appears to depend also on the low buffer capacity of initial sand as well as on its poverty in metals capable of neutralizing acids of litter origin (Ponomareva 1964).

\section{Texture and textural changes}

Medium and fine sand are predominant in the whole sandy solum (Table 3). As a result of weathering and pedogenesis, coarse and medium sand have been 
Table 3. Grain-size and physical characteristics

\begin{tabular}{|c|c|c|c|c|c|c|c|c|}
\hline \multirow{2}{*}{$\begin{array}{c}\text { Horizon } \\
\text { and depth, } \mathrm{cm}\end{array}$} & \multicolumn{6}{|c|}{ Grain-size fractions, $\mathrm{g} \mathrm{kg}^{-1}$ of fine earth } & \multirow{2}{*}{$\begin{array}{c}\text { Specific } \\
\text { surface } \\
\text { area, } \mathrm{m}^{2} \mathrm{~g}\end{array}$} & \multirow{2}{*}{$\begin{array}{c}\text { Bulk } \\
\text { density, } \\
\mathrm{Mg} \mathrm{m}^{-3}\end{array}$} \\
\hline & $\begin{array}{c}2-0.5 \\
\mathrm{~mm}\end{array}$ & $\begin{array}{c}0.5-0.25 \\
\mathrm{~mm}\end{array}$ & $\begin{array}{c}0.25-0.1 \\
\mathrm{~mm}\end{array}$ & $\begin{array}{c}0.1-0.05 \\
\mathrm{~mm}\end{array}$ & $\begin{array}{c}0.05-0.002 \\
\mathrm{~mm}\end{array}$ & $\begin{array}{c}<0.002 \\
\mathrm{~mm}\end{array}$ & & \\
\hline A $0-10$ & 69 & 361 & 484 & 54 & 12 & 20 & 15.4 & 1.37 \\
\hline A $10-24$ & 69 & 309 & 504 & 74 & 27 & 17 & 16.4 & 1.42 \\
\hline E 24-50 & 10 & 340 & 495 & 126 & 22 & 7 & 6.2 & 1.45 \\
\hline Bhs $50-75 b^{*}$ & 115 & 370 & 421 & 35 & 45 & 14 & 34.9 & 1.45 \\
\hline Bhs 50-75y* & 80 & 374 & 428 & 95 & 23 & 0 & 29.0 & 1.40 \\
\hline Bs $75-100$ & 160 & 420 & 397 & 1 & 22 & 0 & 16.4 & 1.48 \\
\hline BC 100-120 (180) & 124 & 480 & 338 & 32 & 26 & 0 & 15.4 & 1.49 \\
\hline $\begin{array}{l}C(180) 250-260 \\
(306)\end{array}$ & 167 & 560 & 261 & 1 & 11 & 0 & 4.8 & 1.51 \\
\hline$A(306) 332-342$ & 8 & 282 & 691 & 4 & 15 & 0 & 10.6 & 1.26 \\
\hline AH 342-351 & & & & & & & 299.6 & 0.32 \\
\hline AH $351-360$ & & & & & & & 133.8 & 0.93 \\
\hline IIG 360-370 & 60 & 91 & & 39 & 392 & 118 & 28.0 & 1.81 \\
\hline IICg 370-380 & 54 & 87 & & 16 & 427 & 116 & 26.7 & 1.94 \\
\hline
\end{tabular}

$b^{*}$, brown area within the Bhs-horizon; $y^{*}$, yellow area within the Bhs-horizon.

partly transformed into fine sand, silt, and clay. About a twofold increase in the content of fine sand and a more than 120-fold increase in very fine sand have taken place in the albic horizon, while silt and clay have accumulated in particularly large quantities in the brown area of the spodic horizon. This process has been accompanied with a significant increase in the specific surface area and only a slight decrease in bulk density. Against the background of essential pedogenetic changes in sands, the underlying till has remained practically unchanged during pedogenesis within the Younger Dryas and Pre-Boreal.

Table 4. Changes in the pool of grain-size fractions, $\pm \mathrm{kg} \mathrm{m}^{-2}$

\begin{tabular}{|c|c|c|c|c|c|c|c|c|c|}
\hline \multirow{2}{*}{$\begin{array}{c}\text { Horizon } \\
\text { and thickness, } \\
\mathrm{cm}\end{array}$} & \multicolumn{3}{|c|}{ Sand $(2-0.05 \mathrm{~mm})$ fraction } & \multicolumn{3}{|c|}{ Silt $(0.05-0.002 \mathrm{~mm})$ fraction } & \multicolumn{3}{|c|}{ Clay $(<0.002 \mathrm{~mm})$ fraction } \\
\hline & $\begin{array}{c}\text { Parent } \\
\text { sand }\end{array}$ & Soil & \pm & $\begin{array}{c}\text { Parent } \\
\text { sand }\end{array}$ & Soil & \pm & $\begin{array}{c}\text { Parent } \\
\text { sand }\end{array}$ & Soil & \pm \\
\hline A 10 & 149 & 132 & -17 & 2 & 2 & 0 & 0 & 3 & +3 \\
\hline A 14 & 209 & 190 & -19 & 2 & 6 & +4 & 0 & 3 & +3 \\
\hline E 26 & 389 & 366 & -23 & 4 & 8 & +4 & 0 & 3 & +3 \\
\hline Bhs 25 & 373 & 342 & -31 & 4.5 & 12 & +7.5 & 0 & 3 & +3 \\
\hline Bs 25 & 373 & 362 & -11 & 4.5 & 8 & +3.5 & 0 & 0 & 0 \\
\hline BC 80 & 1195 & 1161 & -34 & 13 & 31 & +18 & 0 & 0 & 0 \\
\hline Total 180 & 2688 & 2553 & -135 & 30 & 67 & +37 & 0 & 12 & +12 \\
\hline
\end{tabular}

Total decrease in initial weight: $-86 \mathrm{~kg} \mathrm{~m}^{-2}$, i.e. $3.16 \%$. 
A total $3.2 \%$ decrease in the uncorrected pool of fine earth in comparison with the initial pool in the sand column is apparent, although with an evident breakdown of sandy fractions (Table 4). The podzolic solum is uniformly enriched with clay, without differentiation between the horizons. By layer status of sandy indicators (Targulian et al. 1974; Reintam 1997b), the Podzol of $180 \mathrm{~cm}$, formed during about 9000 years, represents a result of pedogenetic interactions in the initial sand column which was $9 \mathrm{~cm}$ thinner (Table 5). Judging by changes in organic matter and bulk density (Tables 2 and 3), a loosening and a slight upward expansion of the solum have taken place. The average rate in the upper $75 \mathrm{~cm}$ has been about 6-7 $\mu \mathrm{m} \mathrm{m}^{-2} \mathrm{yr}^{-1}$ and in the deeper part of the profile, about twice lower. Although an accumulation of sand was found not only in the albic horizon, but also in the mellowed yellow area of the spodic horizon, an equal balance of the sand fraction has been formed in the entire profile. Corrected data demonstrate a $1.9 \%$ increase in the pool of grain-size fractions (Table 5). At the expense of silt and formed clay, it makes up only $5.6 \mathrm{~g} \mathrm{~m}^{-2} \mathrm{yr}^{-1}$ per the initial $171 \mathrm{~cm}$ column of Ancylus sand and appears to be related to the prevalence of the accumulative turnover of substances in relation to the removal of weathering products.

Table 5. Changes in the corrected pool of grain-size fractions compared with the smoothed thickness of initial sand, $\pm \mathrm{kg} \mathrm{m}^{-2}$

\begin{tabular}{|c|c|c|c|c|c|c|c|c|c|}
\hline \multirow{2}{*}{$\begin{array}{l}\text { Horizon and } \\
\text { smoothed } \\
\text { thickness of } \\
\text { initial sand, } \\
\mathrm{cm}\end{array}$} & \multicolumn{3}{|c|}{ Sand $(2-0.05 \mathrm{~mm})$ fraction } & \multicolumn{3}{|c|}{ Silt $(0.05-0.002 \mathrm{~mm})$ fraction } & \multicolumn{3}{|c|}{ Clay $(<0.002 \mathrm{~mm})$ fraction } \\
\hline & $\begin{array}{l}\text { Corrected } \\
\text { parent sand }\end{array}$ & Soil & \pm & $\begin{array}{l}\text { Corrected } \\
\text { parent sand }\end{array}$ & Soil & \pm & $\begin{array}{l}\text { Corrected } \\
\text { parent sand }\end{array}$ & Soil & \pm \\
\hline A 22 & 328 & 322 & -6 & 4 & 8 & +4 & 0 & 6 & +6 \\
\hline E 24 & 359 & 366 & +7 & 4 & 8 & +4 & 0 & 3 & +3 \\
\hline Bhs 23 & 343 & 342 & -1 & 4 & 12 & +8 & 0 & 3 & +3 \\
\hline Bs 24 & 358 & 362 & +4 & 4 & 8 & +4 & 0 & 0 & 0 \\
\hline BC 78 & 1165 & 1161 & -4 & 13 & 31 & +18 & 0 & 0 & 0 \\
\hline Total 171 & 2553 & 2553 & 0 & 29 & 67 & +38 & 0 & 12 & +12 \\
\hline
\end{tabular}

Total increase in initial pool: $50 \mathrm{~kg} \mathrm{~m}^{-2}$, i.e. $1.9 \%$.

\section{Mineral composition}

The light mineral suite of medium and fine sand consists mainly of quartz (Fig. 5) whose content decreases simultaneously with an increase in the content of feldspars in more dispersed fractions. Micas have preserved only in very fine sand. Different aggregates and some fragments of a phosphatic fauna are present in the fine sand of the epipedon. Some rare glauconite, chalcedony, and carbonates are contained in places in the fractions of fine and very fine sand. Against the 


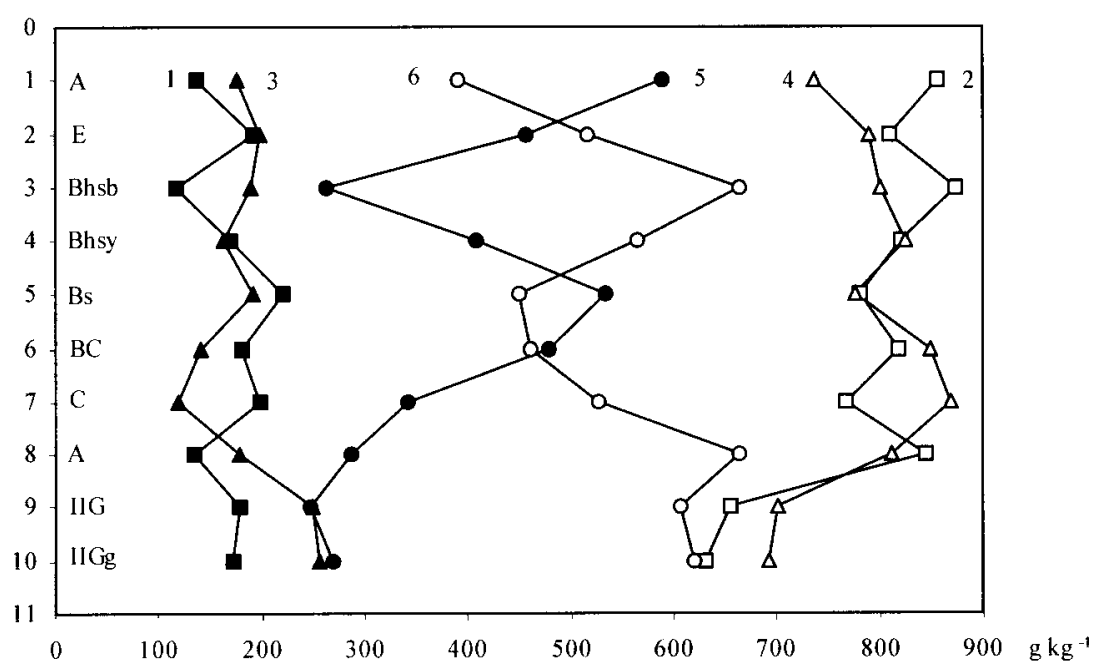

Fig. 5. Profile distribution of the light mineral suite $\left(\mathrm{g} \mathrm{kg}^{-1}\right)$. 1, feldspars in the $0.5-0.25 \mathrm{~mm}$ fraction; 2, quartz in the $0.5-0.25 \mathrm{~mm}$ fraction; 3, feldspars in the $0.25-0.1 \mathrm{~mm}$ fraction; 4, quartz in the $0.25-0.1 \mathrm{~mm}$ fraction; 5, feldspars in the $0.1-0.05 \mathrm{~mm}$ fraction; 6 , quartz in the $0.1-0.05 \mathrm{~mm}$ fraction.

background of pure and/or slightly pigmented grains of quartz and feldspars in initial sand, both the ochric epipedon and the spodic horizon are characterized by pigmentation of mainly pedogenetic origin. Only the albic horizon is almost free from pigments.

The finer sand particles, the lower is the quartz to feldspars ratio (Table 6). The increase in quartz and the decrease in feldspars in the brown-coloured part of the spodic horizon has resulted in a significant increase in their ratio (Fig. 5, Table 6). Among the feldspars, orthoclase (65-89\%) predominates in all mineral suites, while its slight, 3-12\% upward decrease seems to be simultaneous with the slight increase in the content of plagioclase (10-23\%), displayed about the same extent in the podzolic subsection. Contrary to the opinion of Melkerud et al. (2000), plagioclase (mainly alkalic plagioclase of the anorthite type) appears to be a little more resistant to acid hydrolysis than orthoclase. Microcline accounts for only some per cent of feldspars, which is a little more preserved in the albic horizon and has disappeared from the spodic horizon. The light mineral suite in gleyed calcareous till is practically unchanged, its quartz content being about $20 \%$ lower compared with sand (Fig. 5, Table 6). Except for very fine sand, till is characterized by relative richness in feldspars, while its orthoclase to plagioclase ratio is somewhat higher than the respective ratio for sand. The degree of quartz rounding is similar throughout both the podzolic and gleyic profiles (Table 6), demonstrating the same principal origin of quartz in till as well as in the sand of Ancylus age. 
Table 6. Characteristics of the light fraction and total heavy mineral suite $\left(\mathrm{g} \mathrm{kg}^{-1}\right)$

\begin{tabular}{l|c|c|c|c|c|c|c}
\hline \multirow{2}{*}{$\begin{array}{c}\text { Horizon and depth, } \\
\mathrm{cm}\end{array}$} & \multicolumn{3}{|c|}{ Quartz: feldspars ratio } & \multicolumn{2}{c|}{$\begin{array}{c}\text { Degree of quartz } \\
\text { rounding }\end{array}$} & \multicolumn{2}{c}{$\begin{array}{c}\text { Total heavy mineral } \\
\text { suite in fractions }\end{array}$} \\
\cline { 2 - 8 } & $\begin{array}{c}0.5-0.25 \\
\mathrm{~mm}\end{array}$ & $\begin{array}{c}0.25-0.1 \\
\mathrm{~mm}\end{array}$ & $\begin{array}{c}0.1-0.05 \\
\mathrm{~mm}\end{array}$ & $\begin{array}{c}0.25-0.1 \\
\mathrm{~mm}\end{array}$ & $\begin{array}{c}0.1-0.05 \\
\mathrm{~mm}\end{array}$ & $\begin{array}{c}0.25-0.1 \\
\mathrm{~mm}\end{array}$ & $\begin{array}{c}0.1-0.05 \\
\mathrm{~mm}\end{array}$ \\
\hline A 0-10 & 5.3 & 3.3 & 0.6 & 0.41 & 0.33 & 31 & 90 \\
A 10-24 & 7.5 & 5.5 & 0.7 & 0.38 & 0.34 & 20 & 60 \\
E 24-50 & 4.2 & 4.0 & 1.2 & 0.39 & 0.31 & 9 & 180 \\
Bhs 50-756* & 7.5 & 4.2 & 2.5 & 0.40 & 0.33 & 16 & 108 \\
Bhs 50-75y* & 4.8 & 5.1 & 1.4 & 0.39 & 0.38 & 23 & 138 \\
Bs 75-100 & 3.5 & 4.1 & 0.8 & 0.38 & 0.34 & 52 & 130 \\
BC 100-120 (180) & 4.5 & 6.0 & 1.0 & 0.39 & 0.34 & 48 & 137 \\
C (180) 250-260 (306) & 3.9 & 7.3 & 1.6 & 0.41 & 0.37 & 20 & 83 \\
A (306) 332-342 & 6.3 & 4.6 & 2.3 & 0.38 & 0.33 & 33 & 53 \\
IIG 360-370 & 3.7 & 2.8 & 2.5 & 0.38 & 0.33 & 11 & 18 \\
IICg 370-380 & 3.7 & 2.7 & 2.3 & 0.34 & 0.31 & 9 & 22 \\
\end{tabular}

$b^{*}$, brown area within the Bhs-horizon; $y^{*}$, yellow area within the Bhs-horizon.

As a result of the weathering of the fractions coarser than $0.25 \mathrm{~mm}$ and the development of podzolization, both quartz and feldspars have accumulated in fractions finer than $0.25 \mathrm{~mm}$ (Table 7). Their total increment makes up about $6.5 \%$ of their initial amount in the analysed fractions. While the pool of the whole sand fraction of the studied Podzol is balanced (Table 5), such a growth in the main mineral constituents can be associated only with changes in the interfraction proportions. Taking into account changes in the texture of coarse sand (Table 3), the increase in the fine fractions $\left(168 \mathrm{~kg} \mathrm{~m}^{-2}\right.$ per the initial column of $171 \mathrm{~cm}$ ) appears to have occurred at the expense of the input from the former when the average rate of the breakdown of coarser particles was about 35-40\%. In fact, the breakdown rate for the ochric, albic, and spodic horizons has been about

Table 7. Corrected changes in the pool of the light mineral suite of sand fractions, $\mathrm{kg} \mathrm{m}^{-2}$

\begin{tabular}{|c|c|c|c|c|c|c|c|c|c|}
\hline \multirow{2}{*}{$\begin{array}{c}\text { Hori- } \\
\text { zon }\end{array}$} & \multicolumn{3}{|c|}{ Quartz } & \multicolumn{3}{|c|}{ Feldspars } & \multicolumn{3}{|c|}{ Micas } \\
\hline & $\begin{array}{c}0.5-0.25 \\
\mathrm{~mm}\end{array}$ & \begin{tabular}{|c|}
$0.25-0.1$ \\
$\mathrm{~mm}$
\end{tabular} & $\begin{array}{c}0.1-0.05 \\
\mathrm{~mm}\end{array}$ & $\begin{array}{c}0.5-0.25 \\
\mathrm{~mm}\end{array}$ & $\begin{array}{c}0.25-0.1 \\
\mathrm{~mm}\end{array}$ & $\begin{array}{c}0.1-0.05 \\
\mathrm{~mm}\end{array}$ & $\begin{array}{c}0.5-0.25 \\
\mathrm{~mm}\end{array}$ & \begin{tabular}{|c|}
$0.25-0.1$ \\
$\mathrm{~mm}$
\end{tabular} & $\begin{array}{c}0.1-0.05 \\
\mathrm{~mm}\end{array}$ \\
\hline A & -47.5 & +47.9 & +8.6 & -22.0 & +17.8 & +12.7 & -2.2 & -1.1 & +0.3 \\
\hline $\mathrm{E}$ & -57.2 & +64.8 & +24.3 & -15.9 & +25.8 & +21.5 & -2.4 & -1.2 & +0.7 \\
\hline Bhs & -36.4 & +44.6 & +13.2 & -19.9 & +16.0 & +8.1 & -2.3 & -1.2 & +0.8 \\
\hline Bs & -34.4 & +31.9 & 0 & -6.1 & +16.9 & +0.1 & -2.3 & -0.3 & 0 \\
\hline $\mathrm{BC}$ & -37.4 & +75.3 & +16.9 & -27.6 & +20.2 & +17.9 & -7.4 & -0.2 & +1.7 \\
\hline \multirow[t]{2}{*}{ Total } & -212.9 & +264.5 & +63.0 & -91.5 & +96.7 & +60.3 & -16.6 & -4.0 & +3.5 \\
\hline & & +119.6 & & & +65.5 & & & -17.1 & \\
\hline
\end{tabular}


60,90 , and $40 \%$, respectively, although in the Bs-BC sequence (accounting for about $55 \%$ of changes in the fraction pool) the proportion of textural changes has formed only about $25 \%$. These calculations confirm the subsequent weathering of particles of different size and the relative enrichment of finer particles in resistant residual constituents. The total rate of interfraction changes in the pool of quartz and feldspars appears to be about $\pm 50 \mathrm{~g} \mathrm{~m}^{-2} \mathrm{yr}^{-1}$ per entire solum, which makes about $\pm 0.3 \mathrm{~g} \mathrm{~m}^{-2} \mathrm{yr}^{-1} \mathrm{~cm}^{-1}$.

Compared with fine sand the content of the heavy mineral suite in very fine sand is many times larger (Table 6). In both cases, the mineral composition of the sand of the underlying till is poorer than that of the overlying sand. Except for the $0.25-0.1 \mathrm{~mm}$ fraction of the podzolized A-E-Bhs sequence, the solum is enriched with the heavy mineral suite in comparison with the unchanged material lying deeper than $180 \mathrm{~cm}$. On the basis of the data on the light mineral suite, the residual enrichment of the fine sand of the solum with the heavy mineral suite can be ascribed to the more intensive weathering of the coarser fractions and to total decrease in the content of coarse and medium sand (Tables 3-5). The largest increase in the heavy mineral suite in the very fine sand of the albic horizon appears to be caused by the peak weathering and acid hydrolysis of the coarser fractions therein. An increase in the content of ore minerals and/or their eluvio-illuvial distribution were induced by the weathering of amphiboles and pyroxenes, which has been described by means of highly significant $\left(r=0.80^{* * *}-0.85^{* * *}\right)$ regression equations (Kitse \& Reintam 1973). In spite of the ready subjection of amphiboles and pyroxenes to chemical weathering, hornblende is relatively resistant under an acid reaction (Haseman \& Marshall 1945), particularly in the composition of sand fractions (Cady 1960). Therefore its residual accumulation in the albic horizon is evident against the background of a decrease in pyroxenes and garnets (Fig. 6). The heavy mineral suite of fine sand is totally impoverished in micas, garnets, and carbonates. Like ore minerals and/or amphiboles, the epidote in both fractions and garnets in very fine sand display evident residual accumulation with a maximum in the albic horizon. Zircon distribution is typical of acid hydrolysis; the layer diversity of the profile with respect to tourmaline, kyanite, staurolite, rutile, and sphene appears to be related not only to the weathering, but also to the initial heterogeneity of wind affected sediment.

The increase in ilmenite, magnetite, and garnets together with the simultaneous decrease in iron hydroxides, micas, pyroxenes, and carbonates can be ascribed to the strongly gleyed part of till beneath the molli-histic epipedon of Younger Dryas-Pre-Boreal Gleysol (Fig. 6). Amphiboles, leucoxene, and tourmaline are actually unchanged. Apatite and pyrite are present in the fine sand of till, but are in most cases lacking in the wind reworked deposits. The interfraction transformation of zircon seems to have been taken place under the impact of the gleying on till. 


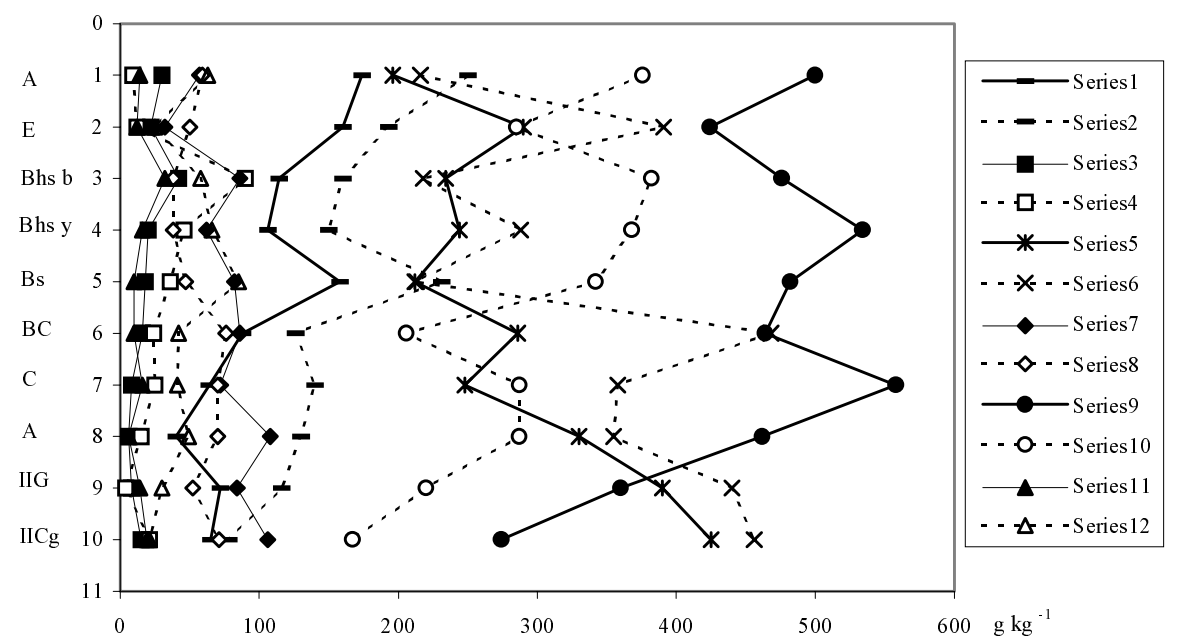

Fig. 6. Profile distribution of the heavy mineral suite $\left(\mathrm{g} \mathrm{kg}^{-1}\right)$. Ilmenite, magnetite: 1 , in the $0.25-$ $0.1 \mathrm{~mm}$ fraction; 2, in the $0.1-0.05 \mathrm{~mm}$ fraction. Fe-hydroxides: 3 , in the $0.25-0.1 \mathrm{~mm}$ fraction; 4 , in the $0.1-0.05 \mathrm{~mm}$ fraction. Amphiboles: 5 , in the $0.25-0.1 \mathrm{~mm}$ fraction; 6 , in the $0.1-0.05 \mathrm{~mm}$ fraction. Pyroxenes: 7 , in the $0.25-0.1 \mathrm{~mm}$ fraction; 8 , in the $0.1-0.05 \mathrm{~mm}$ fraction. Garnet: 9 , in the $0.25-0.1 \mathrm{~mm}$ fraction; 10 , in the $0.1-0.05 \mathrm{~mm}$ fraction. Zircon: 11 , in the $0.25-0.1 \mathrm{~mm}$ fraction; 12 , in the $0.1-0.05 \mathrm{~mm}$ fraction.

\section{Chemical constituents and their changes}

Even without any balance corrections to the depth and weight of the horizons, the distribution of elements in the sand solum is clearly eluvial (podzolic) (Table 8). A breakdown of alumosilicates and a considerable translocation of most elements have taken place. Some alkaline earths seem to be accumulated in the humous horizon above the buried histic epipedon of Gleysol. Due to the presence of rutile and sphene, the underlying calcareous till is extremely rich in titanium. The concentration of iron, aluminium, and titanium is a little higher in the brown area of the spodic horizon than in its yellow area. This demonstrates the heterogeneous distribution of the chelatic input from the uppermost eluvial solum. The removal of silica is not diagnosed. Losses from the A-E sequence are much smaller than the input into the Bhs-Bs sequence. It means that a large part of illuviated sesquioxides appear to be derived from forest litter over time, as it was ascertained for the Nordic Podzols (Giesler et al. 2000).

Although the total increase in elements $\left(25.7 \mathrm{~kg} \mathrm{~m}^{-2}\right)$ per solum with an initial sand thickness of $171 \mathrm{~cm}$ was ascertained, the corrected depth and weight of initial sand (Table 5) demonstrate the podzolic origin of changes in the pool of chemical constituents (Table 9). This figure is in good agreement with the respective figure for the textural fractions (Table 5). In spite of total profile accumulativeness 
Table 8. Chemical composition $\left(\mathrm{g} \mathrm{kg}^{-1}\right)$ of horizons per ignited noncalcareous material

\begin{tabular}{|c|c|c|c|c|c|c|c|c|c|c|c|}
\hline \multirow[t]{2}{*}{ Component } & \multicolumn{11}{|c|}{ Horizon and depth, cm } \\
\hline & $\begin{array}{c}\mathrm{A} \\
0-10\end{array}$ & $\begin{array}{c}\text { A } \\
10-24\end{array}$ & $\begin{array}{c}\mathrm{E} \\
24-50\end{array}$ & $\begin{array}{c}\text { Bhs } \\
50-75 b^{*}\end{array}$ & $\begin{array}{c}\text { Bhs } \\
50-75 y^{*}\end{array}$ & $\begin{array}{c}\text { Bs } \\
75-100\end{array}$ & $\begin{array}{c}\mathrm{BC} \\
100-120(180)\end{array}$ & $\begin{array}{c}\mathrm{C} \\
(180) 250-260 \\
(306)\end{array}$ & $\begin{array}{c}\mathrm{A} \\
\text { (306) } 332-342\end{array}$ & $\begin{array}{c}\text { IIG } \\
360-370\end{array}$ & $\begin{array}{c}\mathrm{IICg} \\
370-380\end{array}$ \\
\hline $\mathrm{Si}$ & 426.0 & 434.3 & 437.8 & 428.2 & 422.4 & 424.7 & 419.6 & 431.5 & 415.8 & 388.3 & 331.4 \\
\hline $\mathrm{Fe}$ & 5.7 & 3.4 & 2.0 & 7.6 & 6.7 & 5.5 & 5.1 & 3.2 & 6.4 & 22.7 & 22.2 \\
\hline $\mathrm{Al}$ & 14.8 & 16.3 & 14.2 & 26.2 & 25.3 & 22.4 & 23.2 & 19.9 & 22.0 & 51.7 & 48.9 \\
\hline $\mathrm{Ti}$ & 3.3 & 1.8 & 0.8 & 1.4 & 1.1 & 2.4 & 1.5 & 0.9 & 6.2 & 14.2 & 13.1 \\
\hline $\mathrm{P}$ & 0.1 & 0.2 & 0.1 & 0.1 & 0.1 & 0.1 & 0.1 & 0.0 & 0.1 & 0.1 & 0.1 \\
\hline $\mathrm{Ca}$ & 4.0 & 3.2 & 1.4 & 2.2 & 4.1 & 3.2 & 3.1 & 2.3 & 3.9 & 34.6 & 33.7 \\
\hline $\mathrm{Mg}$ & 2.0 & 1.6 & 1.2 & 1.9 & 2.1 & 1.9 & 2.1 & 1.8 & 2.4 & 32.1 & 30.4 \\
\hline K & 13.7 & 13.8 & 8.5 & 7.9 & 13.6 & 11.9 & 10.3 & 9.0 & 11.3 & 25.6 & 26.8 \\
\hline $\mathrm{Na}$ & 3.8 & 3.2 & 3.5 & 5.5 & 4.5 & 5.6 & 5.8 & 5.1 & 4.2 & 5.7 & 4.9 \\
\hline $\mathrm{Mn}$ & 2.1 & 1.1 & 1.2 & 1.1 & 1.2 & 1.0 & 2.2 & 1.1 & 0.5 & 0.9 & 1.1 \\
\hline $\mathrm{CaCO}_{3}$ & & & & & & & & & 6.2 & 189 & 189 \\
\hline
\end{tabular}

$b^{*}$, brown area within the Bhs-horizon; $y^{*}$, yellow area within the Bhs-horizon. 
Table 9. Changes in the pool of chemical elements compared with the corrected thickness of initial sand, $\pm \mathrm{g} \mathrm{m}^{-2}$

\begin{tabular}{|c|c|c|c|c|c|c|c|}
\hline Element & Material & A $24 \mathrm{~cm}$ & E $26 \mathrm{~cm}$ & Bhs $25 \mathrm{~cm}$ & Bs $25 \mathrm{~cm}$ & BC $80 \mathrm{~cm}$ & Total $180 \mathrm{~cm}$ \\
\hline \multirow[t]{3}{*}{$\mathrm{Si}$} & Soil & 144788 & 165051 & 151893 & 157139 & 500163 & 1119034 \\
\hline & Initial sand & 143258 & 156635 & 149731 & 156203 & 508307 & 1114134 \\
\hline & \pm & +1530 & +8416 & +2 162 & +936 & -8144 & +4900 \\
\hline \multirow[t]{3}{*}{$\mathrm{Fe}$} & Soil & 1258 & 754 & 2511 & 2035 & 7261 & 13819 \\
\hline & Initial sand & 1063 & 1162 & 1111 & 1159 & 3770 & 8265 \\
\hline & \pm & +195 & -408 & +1400 & +876 & +3491 & +5554 \\
\hline \multirow[t]{3}{*}{$\mathrm{Al}$} & Soil & 5272 & 5353 & 9202 & 8288 & 27654 & 55769 \\
\hline & Initial sand & 6607 & 7224 & 6905 & 7204 & 23442 & 51382 \\
\hline & \pm & -1335 & -1871 & +2297 & +1084 & +4 212 & +4 387 \\
\hline \multirow[t]{3}{*}{$\mathrm{Ti}$} & Soil & 810 & 302 & 450 & 888 & 1788 & 4238 \\
\hline & Initial sand & 299 & 327 & 312 & 326 & 1060 & 2324 \\
\hline & \pm & +511 & -25 & +138 & +562 & +728 & +1914 \\
\hline \multirow[t]{3}{*}{$\mathrm{P}$} & Soil & 54 & 38 & 36 & 37 & 119 & 284 \\
\hline & Initial sand & 0 & 0 & 0 & 0 & 0 & 0 \\
\hline & \pm & +54 & +38 & +36 & +37 & +119 & +284 \\
\hline \multirow[t]{3}{*}{$\mathrm{Ca}$} & Soil & 1185 & 528 & 1122 & 1184 & 3695 & 7714 \\
\hline & Initial sand & 764 & 835 & 798 & 833 & 2709 & 5939 \\
\hline & \pm & +421 & -307 & +324 & +351 & +986 & +1775 \\
\hline \multirow[t]{3}{*}{$\mathrm{Mg}$} & Soil & 592 & 452 & 712 & 703 & 2503 & 4962 \\
\hline & Initial sand & 598 & 653 & 625 & 652 & 2120 & 4648 \\
\hline & \pm & -6 & -201 & +87 & +51 & +383 & +314 \\
\hline \multirow[t]{3}{*}{ K } & Soil & 4623 & 3204 & 3778 & 4403 & 12278 & 28286 \\
\hline & Initial sand & 2988 & 3267 & 3123 & 3258 & 10602 & 23238 \\
\hline & \pm & +1635 & -63 & +655 & +1145 & +1676 & +5048 \\
\hline \multirow[t]{3}{*}{$\mathrm{Na}$} & Soil & 1158 & 1320 & 1796 & 2072 & 6913 & 13259 \\
\hline & Initial sand & 1693 & 1851 & 1770 & 1846 & 6008 & 13168 \\
\hline & \pm & -535 & -531 & +26 & +226 & +905 & +91 \\
\hline \multirow[t]{3}{*}{$\mathrm{Mn}$} & Soil & 407 & 452 & 410 & 370 & 2622 & 4261 \\
\hline & Initial sand & 365 & 399 & 382 & 398 & 1296 & 2840 \\
\hline & \pm & +42 & +53 & +28 & -28 & +1326 & +1421 \\
\hline \multirow[t]{3}{*}{ Total } & Soil & 160147 & 177454 & 171910 & 177119 & 564996 & 1251626 \\
\hline & Initial sand & 157635 & 172353 & 164757 & 171879 & 559314 & 1225938 \\
\hline & \pm & +2512 & +5 101 & +7153 & +5240 & +5682 & +25688 \\
\hline \multirow{3}{*}{$\begin{array}{l}\text { Weight, } \\
\mathrm{kg} \mathrm{m}^{-2}\end{array}$} & Soil & 336 & 377 & 357 & 370 & 1192 & 2632 \\
\hline & Initial sand & 332 & 363 & 347 & 362 & 1178 & 2582 \\
\hline & \pm & +4 & +14 & +10 & +8 & +14 & $+\mathbf{5 0}$ \\
\hline
\end{tabular}

The sum of the elements in initial sand $47.5 \%$, increase in the elements $2.1 \%$. 
$(\mathrm{Fe}>\mathrm{K}>\mathrm{Si}>\mathrm{Al}>\mathrm{Ti}>\mathrm{Ca}>\mathrm{Mn}>\mathrm{Mg}>\mathrm{P}>\mathrm{Na})$, the A-E-Bhs sequence is eluvial with respect to three elements $(\mathrm{Na}>\mathrm{Al}>\mathrm{Mg})$, the $\mathrm{A}-\mathrm{E}$ sequence, with respect to four elements $(\mathrm{Al}>\mathrm{Na}>\mathrm{Fe}>\mathrm{Mg})$, and the albic $(\mathrm{E})$ horizon, with respect to as many as seven elements $(\mathrm{Al}>\mathrm{Na}>\mathrm{Fe}>\mathrm{Ca}>\mathrm{Mg}>\mathrm{K}>\mathrm{Ti}$ ). Only $\mathrm{Si}$ has accumulated in large amounts in the albic horizon. These sequences are similar to those presented for podzolized pedons in Sweden and Finland (Olsson \& Melkerud 2000) and in large areas worldwide (Rode 1937; Muir 1961; Ponomareva 1964). The average annual loss of $\mathrm{Fe}, \mathrm{Al}, \mathrm{Mg}$, and $\mathrm{Na}$ $\left(0.522 \mathrm{~g} \mathrm{~m}^{-2} \mathrm{yr}^{-1}\right)$ from the A-E sequence of Podzol at Lemmejõgi is compensated for by the residual accumulation of silica $\left(1.105 \mathrm{~g} \mathrm{~m}^{-2} \mathrm{yr}^{-1}\right)$, which is about twofold larger than the losses $\left(0.583 \mathrm{~g} \mathrm{~m}^{-2} \mathrm{yr}^{-1}\right)$. A similar situation is characteristic of the albic horizon: the losses of $\mathrm{Fe}, \mathrm{Al}, \mathrm{Ti}, \mathrm{Ca}, \mathrm{Mg}, \mathrm{K}$, and $\mathrm{Na}\left(0.378 \mathrm{~g} \mathrm{~m}^{-2} \mathrm{yr}^{-1}\right)$ are exceeded by the residual accumulation of silica $\left(0.935 \mathrm{~g} \mathrm{~m}^{-2} \mathrm{yr}^{-1}\right)$ by $0.557 \mathrm{~g} \mathrm{~m}^{-2} \mathrm{yr}^{-1}$. This suggests that the proportion of resistant to weathering quartz was essential already in initial coarse material transformed by the wind. The phenomenon serves also as an argument in the explanation of the abovediscussed changes in texture and mineral constituents.

There is no doubt that during the moist and warm Litorina Sea Stage, the ground water table must have been much nearer to surface. The spodic horizon was formed first at the boundary of the fluctuating capillary fringe, as in most contemporary humus-illuvial formations (Ponomareva 1964; Reintam 1997a; Harris \& Hollien 2000). It is possible that the albic horizon was then weaker and the epipedon was at least umbric. The decrease in the ground water table led to the progress of podzolization in the presence of small amounts of fulvic compounds and fixation of $\mathrm{R}_{2} \mathrm{O}_{3}$-chelates within a relatively thick layer traversed by slightly cemented stripes of geological and/or pedogenetic origin. If Al-humic-fulvic compounds had been present in the brown area of the spodic horizon, they had been transformed over time, leaving only an essential enrichment of the area with aluminium of different nature (Tables 9 and 10).

\section{Nonsiliceous substances}

Both forms of nonsiliceous iron as well as amorphous aluminium and silica display the profile distribution of podzolic origin (Table 10). Podzolization is also evidenced by the ratios of dithionite-extractable iron to both clay and silt. According to Blume (1990), these ratios may characterize not only gleyic and stagnic but also luvic and podzolic properties. Iron activity is higher in initial sand and in the albic horizon where the amount of amorphous substances is inconsiderable. The low proportion of amorphous iron demonstrates the relatively rapid recrystallization of weathering products, while its rate is $0.428 \mathrm{~g} \mathrm{~m}^{-2} \mathrm{yr}^{-1}$ against the background of the total average mobilization $\left(0.664 \mathrm{~g} \mathrm{~m}^{-2} \mathrm{yr}^{-1}\right)$ of nonsiliceous iron. The distribution of amorphous silica is clearly podzolic, the substantial balance $\left(-227\right.$ and $\left.+221 \mathrm{~g} \mathrm{~m}^{-2}\right)$ being observed in the eluvial and 
Table 10. Content of nonsiliceous substances, $\mathrm{g} \mathrm{kg}^{-1}$

\begin{tabular}{|c|c|c|c|c|c|c|c|c|c|c|}
\hline \multirow[t]{2}{*}{$\begin{array}{l}\text { Horizon and } \\
\text { depth, cm }\end{array}$} & \multirow{2}{*}{$\begin{array}{c}\text { Dithionite- } \\
\text { extractable } \\
\mathrm{Fe}\left(\mathrm{Fe}_{\mathrm{d}}\right)\end{array}$} & \multicolumn{3}{|c|}{ Oxalate-extractable } & \multirow{2}{*}{$\begin{array}{c}\text { Fe-ac- } \\
\text { tivity, } \\
\%\end{array}$} & \multirow[t]{2}{*}{$\begin{array}{l}\mathrm{Fe}_{\mathrm{d}}: \\
\text { clay }\end{array}$} & \multirow[t]{2}{*}{$\mathrm{Fe}_{\mathrm{d}}:$ silt } & \multirow{2}{*}{$\begin{array}{r}\begin{array}{l}\text { Amor- } \\
\text { phous }\end{array} \\
\mathrm{Fe} \\
\end{array}$} & \begin{tabular}{|l|} 
Crys- \\
talline
\end{tabular} & \multirow{2}{*}{$\begin{array}{l}\text { Sili- } \\
\text { ceous }\end{array}$} \\
\hline & & $\mathrm{Fe}$ & $\mathrm{Al}$ & $\mathrm{Si}$ & & & & & $\%$ of to & \\
\hline A $0-10$ & 3.6 & 0.8 & 0.7 & 0.7 & 22.2 & 0.18 & 0.30 & 14 & 49 & 37 \\
\hline A $10-24$ & 1.4 & 0.4 & 0.3 & 0.7 & 28.6 & 0.08 & 0.05 & 12 & 29 & 59 \\
\hline E $24-50$ & 1.4 & 0.7 & 0.1 & 0.8 & 50.0 & 0.20 & 0.06 & 35 & 35 & 30 \\
\hline Bhs $50-75 b^{*}$ & 4.8 & 1.2 & 2.4 & 1.5 & 25.0 & 0.34 & 0.12 & 16 & 47 & 37 \\
\hline Bhs 50-75y* & 4.8 & 1.4 & 3.0 & 1.0 & 29.2 & 0.48 & 0.21 & 21 & 51 & 28 \\
\hline Bs $75-100$ & 3.5 & 1.2 & 1.3 & 1.5 & 34.3 & 0.35 & 0.16 & 22 & 42 & 36 \\
\hline $\begin{array}{l}\text { BC } 100-120 \\
(180)\end{array}$ & 1.8 & 0.4 & 1.1 & 0.9 & 22.2 & 0.18 & 0.07 & 8 & 27 & 65 \\
\hline $\begin{array}{l}C(180) 250-260 \\
(306)\end{array}$ & 0.2 & 0.1 & 0.2 & 1.1 & 50.0 & 0.20 & 0.02 & 3 & 3 & 94 \\
\hline A (306) 332-342 & 3.3 & 0.9 & 0.3 & 1.2 & 27.3 & 0.33 & 0.22 & 14 & 38 & 48 \\
\hline AH 342-351 & 11.9 & 2.0 & 1.0 & 2.4 & 16.8 & & & & & \\
\hline AH $351-360$ & 9.6 & 1.6 & 0.9 & 0.8 & 16.7 & & & & & \\
\hline IIG 360-370 & 10.0 & 3.1 & 0.5 & 1.7 & 31.0 & 0.08 & 0.03 & 14 & 30 & 56 \\
\hline IICg 370-380 & 15.5 & 5.5 & 3.6 & 0.7 & 35.5 & 0.13 & 0.04 & 25 & 45 & 30 \\
\hline
\end{tabular}

$b^{*}$, brown area within the Bhs-horizon; $y^{*}$, yellow area within the Bhs-horizon.

illuvial sequences, respectively. The albic horizon is eluvial with respect to amorphous aluminium, yet it has accumulated in the profile $\left(0.386 \mathrm{~g} \mathrm{~m}^{-2} \mathrm{yr}^{-1}\right)$, especially in the spodic horizon. Like in Nordic areas (Giesler et al. 2000), this aluminium appears to be derived from forest litter which in Estonian coniferous forests is rich in sesquioxides (Kõlli 1971).

The relationships of amorphous substances in buried Molli-Histic Gleysol on till (Table 10) show that a decrease in nonsiliceous iron and its ratios to textural constituents, and in amorphous sesquioxides has taken place under the influence of gleying. Proceeding from former interpretations (Brinkman 1979; Blume 1990; Reyntam \& Tsobel 1991; Reintam 2000), these changes can represent the result of ferrolysis, segregation, and surface gleying against the background of former ground gleying, while a neoformation of ferrosilicates must have taken place. Amorphous silica has concentrated in the gleyed horizon beneath the histic epipedon.

\section{Physico-chemical relationships}

Contemporary human activity appears to be related to decrease in exchange acidity and mobile aluminium, and to increase in $\mathrm{pH}$ and base saturation, which are unusual for podzolization in any case (Table 11). Because of the lack of definite evidence it is difficult to guess the cause of such saturation. A most probable source could be alkaline atmospheric deposition from the vicinity of the 
Table 11. Physico-chemical properties

\begin{tabular}{|c|c|c|c|c|c|c|c|c|c|c|c|}
\hline \multirow[t]{2}{*}{ Horizon and depth, cm } & \multicolumn{2}{|c|}{$\mathrm{pH}$} & \multicolumn{5}{|c|}{ Exchangeable bases, $\mathrm{cmol} \mathrm{kg}^{-1}$} & \multicolumn{2}{|c|}{$\begin{array}{l}\text { Exchange acidity, } \\
\mathrm{cmol} \mathrm{kg}^{-1}\end{array}$} & \multirow[t]{2}{*}{$\mathrm{Al} \mathrm{kg}^{3+}$} & \multirow{2}{*}{$\begin{array}{c}\text { Base } \\
\text { saturation, } \\
\%\end{array}$} \\
\hline & $\mathrm{H}_{2} \mathrm{O}$ & $\mathrm{KCl}$ & $\mathrm{Ca}^{2+}$ & $\mathrm{Mg}^{2+}$ & $\mathrm{K}^{+}$ & $\mathrm{Na}^{+}$ & Total & $\mathrm{H}^{+}$ & $\mathrm{Al}^{3+}$ & & \\
\hline A $0-10$ & 5.7 & 5.5 & 2.51 & 0.18 & 0.01 & 0.02 & 2.72 & 0.05 & 0.09 & 8.1 & 95 \\
\hline A $10-24$ & 5.7 & 5.4 & 3.27 & 0.42 & 0.01 & 0.02 & 3.72 & 0.09 & 0.14 & 12.6 & 94 \\
\hline E $24-50$ & 5.8 & 5.5 & 0.25 & 0.05 & 0.01 & 0.01 & 0.32 & 0.05 & 0.04 & 3.6 & 78 \\
\hline Bhs $50-75 b^{*}$ & 5.7 & 5.1 & 1.76 & 0.46 & 0.01 & 0.01 & 2.24 & 0.09 & 0.09 & 8.1 & 93 \\
\hline Bhs 50-75y* & 5.3 & 4.9 & 0.40 & 0.23 & 0.01 & 0.01 & 0.65 & 0.05 & 0.18 & 16.2 & 74 \\
\hline Bs 75-100 & 5.3 & 5.1 & 0.10 & 0.06 & 0.01 & 0.01 & 0.18 & 0.05 & 0.18 & 16.2 & 44 \\
\hline BC 100-120 (180) & 5.6 & 5.5 & 0.10 & 0.08 & 0.01 & 0.01 & 0.20 & 0.05 & 0.09 & 8.1 & 59 \\
\hline C (180) 250-260 (306) & 5.5 & 5.2 & 0.03 & 0.01 & 0.01 & 0.01 & 0.06 & 0.05 & 0.13 & 11.7 & 25 \\
\hline A (306) 332-342 & 6.6 & 6.3 & 1.30 & 0.16 & 0.01 & 0.01 & 1.48 & 0.05 & 0.04 & 3.6 & 64 \\
\hline AH $342-351$ & 6.2 & 5.7 & 26.91 & 0.52 & 0.07 & 0.25 & 27.75 & 0.87 & 0.88 & 79.2 & 94 \\
\hline AH $351-360$ & 6.3 & 5.9 & 19.36 & 0.52 & 0.10 & 0.02 & 20.00 & 0.05 & 0.18 & 16.2 & 99 \\
\hline IIG 360-370 & 7.5 & 7.1 & 8.10 & 0.83 & 0.14 & 0.05 & 9.12 & 0.00 & 0.00 & 0.0 & 100 \\
\hline IICg 370-380 & 7.8 & 7.2 & 8.25 & 0.56 & 0.11 & 0.04 & 8.96 & 0.00 & 0.00 & 0.0 & 100 \\
\hline
\end{tabular}

$b^{*}$, brown area within the Bhs-horizon; $y^{*}$, yellow area within the Bhs-horizon. 
former gravel highway as well as from neighbouring fields. However, also recent changes in the vegetation resulting from the spontaneous introduction of deciduous trees and herbs cannot been excluded. The apparent deposition of alkaline salts by the westerly and northwesterly winds from the sea in the form of drizzle and/or whirl seems to be quite problematic. These phenomena could cause also some enrichment of the topsoil with calcium and potassium (Table 9). The upward saturation from underlying till must be precluded, because in this case podzolization would have been inhibited even in the past when the ground water table was higher.

In spite of the considerable increase in $\mathrm{Ca}^{2+}$ and $\mathrm{Mg}^{2+}$ in the ochric epipedon, BEC of the sandy solum is low (Table 11). Due to the extremely low content of humus and clay, their role in the exchange complex is insignificant and part of base adsorption should be attributed to silt, as Peinemann et al. (2000) suggested on the basis of special studies and literature data. Buried Molli-Histic Gleysol is characterized by many times higher BEC, neutral reaction, almost complete base saturation, and lack of exchange acidity. Only the top of the histic horizon contains some $\mathrm{H}^{+}$and $\mathrm{Al}^{3+}$.

\section{CONCLUSIONS}

Pedogenesis on reddish-brown calcareous till started after the retreat of the Fennoscandian ice-sheet and ice lakes, lasted about 1500-3200 years, and was completed, prior to the Ancylus transgression some $9200 \mathrm{BP}$, with the formation of the AH-BG-BCg sequence of Molli-Histic Gleysol. Against the background of an average rate of organic carbon accumulation of about $5.3-2.5 \mathrm{~g} \mathrm{~m}^{-2} \mathrm{yr}^{-1}$, the evident evolution of Gelic Regosol through Calcaric and Gleyic Regosols and Calcaric Gleysol into Mollic and Molli-Histic Gleysol must have taken place. The histic horizon has been formed during 1000 years at a rate of $12-13 \mathrm{~g} \mathrm{~m}^{-2} \mathrm{yr}^{-1}$ of organic carbon and $0.50 \mathrm{~g} \mathrm{~m}^{-2} \mathrm{yr}^{-1}$ of nitrogen. The gleying of till beneath the histic epipedon of Younger Dryas-Pre-Boreal age has led to some changes in the mineral and chemical relationships characteristic of gleying within any stage of its progress. As a result of the Ancylus transgression and aeolian processes, the section of Molli-Histic Gleysol was buried under sandy sediments at a depth of over $3 \mathrm{~m}$.

Shortly after the beginning of the Ancylus regression stratified beach sands were mostly overblown by coastal winds and, according to pollen and ${ }^{14} \mathrm{C}$ analysis, afforested naturally-spontaneously. Simultaneously with the development of the forest vegetation, soil formation has progressed continuously for approximately 9000 years. As a result, unitary Carbic Podzol with the A-E-Bhs-Bs-BC-C sequence has formed with a total solum thickness of $180 \mathrm{~cm}$. Organic matter as a driving force for pedogenesis has accumulated there at a rate of $1.3 \mathrm{~g} \mathrm{~m}^{-2} \mathrm{yr}^{-1}$. Its distribution in the A-E-Bhs and Bs-BC sequences is 8.1 and $6.7 \mathrm{mg} \mathrm{m}^{-2} \mathrm{yr}^{-1} \mathrm{~cm}^{-1}$, respectively, while ochric $\mathrm{A}$ is humus-accumulative and spodic Bhs is humus- 
illuvial. Evidently, the total fulvicity of humus must have been larger in the past and, under the influence of $\mathrm{R}_{2} \mathrm{O}_{3^{-}}$and/or Ca-fulvic humus, total cheluviation has proceeded at a rate of $55 \mu \mathrm{m} \mathrm{yr}^{-1}$ and formation of the albic horizon, at a rate of $29 \mu \mathrm{m} \mathrm{yr}^{-1}$. As a consequence of weathering and podzolization, initial sand with a thickness of $171 \mathrm{~cm}$ expanded upwards and a solum of $180 \mathrm{~cm}$ was formed, while in the A-E-Bhs sequence the rate of upward expansion was about 6-7 $\mu \mathrm{m} \mathrm{m}^{-2} \mathrm{yr}^{-1}$. This has led to the accumulation of fine pedogenetic products at a rate of $5.6 \mathrm{~g} \mathrm{~m}^{-2} \mathrm{yr}^{-1}$ and the accumulation of soil chemical constituents at a rate of $2.9 \mathrm{~g} \mathrm{~m}^{-2} \mathrm{yr}^{-1}$ in the solum. Nevertheless, the A-E-Bhs sequence is eluvial regarding three elements $(\mathrm{Na}, \mathrm{Al}, \mathrm{Mg})$, the $\mathrm{A}-\mathrm{E}$ sequence is eluvial regarding four elements ( $\mathrm{Al}, \mathrm{Na}, \mathrm{Fe}, \mathrm{Mg}$ ), and the albic (E) horizon is eluvial regarding seven elements ( $\mathrm{Al}, \mathrm{Na}, \mathrm{Fe}, \mathrm{Ca}, \mathrm{Mg}, \mathrm{K}, \mathrm{Ti}$ ). Due to the breakdown of coarse fractions, quartz and feldspars have mainly concentrated in fine sand, while plagioclase appears to be more resistant to acid hydrolysis than orthoclase. The increase in and/or podzolic distribution of ore minerals has been induced by the weathering of pyroxenes and amphiboles, the latter being relatively resistant in coarse fractions and under acid conditions. Against the background of profile accumulativeness, the podzolic distribution of nonsiliceous sesquioxides is characteristic of Carbic Podzol, while profile differentiation with respect to amorphous silica is eluvio-illuvial and shows overall impoverishment. As a consequence of human activity and the impact of some natural agents, an unusual decrease in acidity and exchangeable $\mathrm{Al}^{3+}$ and increase in BEC and base saturation have occurred in the A-E-Bhs sequence of the studied Carbic Podzol.

\section{ACKNOWLEDGEMENTS}

This study was financed by the Estonian Science Foundation (grants Nos. 2669, 4046, and 4195). The final conclusion was made with the support of grant No. 4090. Special thanks go to Ester Jaigma for the linguistic revision of the manuscript and to Ilme Reintam for computer processing. The valuable comments and recommendations of anonymous referees are greatly appreciated.

\section{REFERENCES}

Arinushkina, E. V. 1970. Handbook for Soil Chemical Analyses. Univ. Pr., Moscow (in Russian).

Blume, H.-P. 1990. Soils with gleyic and with stagnic attributes. In Transactions of the 14th International Congress of Soil Science, $\mathbf{V}$, Commission V, pp. 49-54. Kyoto, Japan.

Borken, W., Xu, Y.-J., Brumme, R. \& Lamersdorf, N. 1999. A climate change scenario for carbon dioxide and dissolved organic carbon fluxes from a temperate forest soil: draught and rewetting effects. Soil Sci. Soc. Am. J., 63, 1848-1855.

Brahy, V., Diteux, H., Iserentant, A. \& Delvaux, B. 2000. Surface podzolization in Cambisols under deciduous forest in the Belgium loess belt. European J. Soil Sci., 51, 15-26. 
Brimhall, G. H. \& Dietrich, W. E. 1987. Consecutive mass balance relations between chemical composition, volume, porosity, and strain in metasomatic hydrochemical systems: results in weathering and pedogenesis. Geochim. Cosmochim. Acta, 51, 567-587.

Brinkman, R. 1979. Ferrolysis, a Soil-Forming Process in Hydromorphic Conditions. Pudoc, Wageningen.

Cady, J. G. 1960. Mineral occurrence in relation to soil profile differentiation. Seventh International Congress of Soil Science. Transactions, IV, pp. 418-424. Madison, Wisconsin.

FAO/ISRIC. 1998. World Reference Base for Soil Resources. World Soil Resources Reports, 84. FAO, Rome.

Fichter, J., Turpault, M.-P., Dambrine, E. \& Ranger, J. 1998. Mineral evolution of acid forest soils in the Strengbach catchment (Vosges Mountains, N-E France). Geoderma, 82, 315-340.

Giesler, R., Ilvesniemi, H., Nyberg, L., van Hees, P., Starr, M., Bishop, K., Kareiken, T. \& Lundström, U. S. 2000. Distribution and mobilization of Al, Fe and Si in three podzolic soil profiles in relation to the humus layer. Geoderma, 94, 249-263.

Harris, W. G. \& Hollien, K. A. 2000. Changes across artificial E-Bh boundaries formed under simulated fluctuating water tables. Soil Sci. Soc. Am. J., 64, 967-973.

Haseman, J. F. \& Marshall, C. E. 1945. The use of heavy minerals in studies of the origin and development of soils. Missouri Agricultural Experimental Station. Res. Bull., 387, 1-75.

Katchinskaja, E. S. 1937. Zur Frage der Geschwindigkeit des Verlaufs der Bodenprozesses unter den Bedingungen der Podzoligen Zone. Pochvovedenie (Pedology), 7, 721-728.

Kessel, H. 1963. Holocene coastal formations on the coast of Southwest Estonia. In Materialy po geologii verkhnego pleistotsena i golotsena *stonii (Orviku, K., ed.). ENSV TA Geol. Inst. Uurimused, XII, 123-144

Kessel, H. J. \& Raukas, A. V. 1967. The Deposits of the Ancylus Lake and Littorina Sea in Estonia. Valgus, Tallinn.

Kitse, E. J. \& Reintam, L. J. 1973. On the possible use of regression analysis in soil science. In Primenenie matematicheskikh metodov $i * V M v$ pochvovedenii, pp. 29-32. Dokuchaev Soil Sci. Inst., Moscow (in Russian).

Kitse, E. \& Rooma, I. 1984. Mullateaduse laboratoorne praktikum. Eesti Põllumajanduse Akadeemia, Tartu.

Kõlli, R. 1971. On the relations between vegetation and soils in ecosystems on brown forest and brown pseudopodzolic soils. In Biological Productivity and Regimes of Soils (Reintam, L., ed.). Trans. Estonian Agricult. Acad., 75, 165-202.

Lichter, J. 1998. Rates of weathering and chemical depletion in soils across a chronosequence of Lake Michigan sand dunes. Geoderma, 85, 255-282.

Lundström, U. S., van Breemen, N. \& Bain, D. C. (eds.). 2000a. The Podzolization Process. Geoderma Spec. Issue, 94.

Lundström, U. S., van Breemen, N. \& Bain, D. 2000b. The podzolization process. A review. In The Podzolization Process (Lundström, U. S. et al., eds.). Geoderma, 94, 91-107.

Melkerud, P.-A., Bain, D. C., Jongemans, A. G. \& Tarvainen, T. 2000. Chemical, mineralogical and morphological characterization of three podzols developed on glacial deposits in Northern Europe. In The Podzolization Process (Lundström, U. S. et al., eds.). Geoderma, 94, 125-148.

Mokma, D. L. \& Buurman, P. 1982. Podzols and Podzolization in Temperate Regions. Int. Soil Mus. Monogr., 1.

Muir, A. 1961. The podzol and podzolic soils. Adv. Agronomy, 13, 1-56.

Olsson, M. T. \& Melkerud, P.-A. 2000. Weathering in three podzolized pedons on glacial deposits in northern Sweden and central Finland. In The Podzolization Process (Lundström, U. S. et al., eds.). Geoderma, 94, 149-161.

Peinemann, N., Amiotti, N. M., Zalba, P. \& Villamil, M. B. 2000. Effect of clay minerals and organic matter on the cation exchange capacity of silt fraction. J. Plant Nutr. Soil Sci., 163, $47-52$.

Ponomareva, V. V. 1957. To the method for the study of soil humus after I. V. Tyurin's scheme. Pochvovedenie (Soviet Soil Sci.), 8, 66-71. 
Ponomareva, V. V. 1964. Teoriya podzoloobrazovaniya. Nauka, Moscow-Leningrad (in Russian).

Raukas, A. \& Hyvärinen, H. (eds.). 1992. Geology of the Gulf of Finland. Estonian Acad. Sci., Acad. Finland, Tallinn.

Raukas, A., Kimmel, K. \& Rajamäe, R. 1995a. A new site of buried peat at Lõpe, SW Estonia. Proc. Estonian Acad. Sci. Geol., 44, 133-137.

Raukas, A., Saarse, L. \& Veski, S. 1995b. A new version of the Holocene stratigraphy in Estonia. Proc. Estonian Acad. Sci. Geol., 44, 201-210.

Reintam, L. 1985. Genetic characteristics of soils on red-brown moraine compared by the substance balance method. Soviet Soil Sci., 17, 13-22.

Reintam, L. 1990. Material-regime differentiation of soil profile in diagnostics and classification. In Soil Classification (Rozanov, B. G., ed.), pp. 12-19. UNEP, ISSS. Moscow.

Reintam, L. 1997a. Soil formation. In Geology and Mineral Resources of Estonia (Raukas, A. \& Teedumäe, A., eds.), pp. 298-306. Estonian Acad. Publ., Tallinn.

Reintam, L. 1997b. Pedogenetic changes in the quantity and distribution of textural and chemical soil constituents during thirty years. Proc. Estonian Acad. Sci. Biol. Ecol., 46, 174-190.

Reintam, L. 2000. Surface gleying in forest soils. Baltic Forestry, 6, 2-9.

Reintam, L. \& Moora, T. 1998. Development of pedogenesis on aqueous deposits within the Holocene in West Estonia. Proc. Estonian Acad. Sci. Geol., 47, 108-129.

Reyntam, L. Yu. \& Tsobel, M. R. 1991. Soil formation on calcareous moraines in the Littorina transgression zone. Soviet Soil Sci., 23, 15-24.

Rode, A. A. 1937. The Process of Podzolisation. Izd. AN SSSR, Moscow (in Russian).

Rozanov, B. G. 1975. Genetic Morphology of Soils. Univ. Pr., Moscow (in Russian).

Scholle, P. A. 1979. Color Illustrated Guide to Constituents, Textures, Cements and Porosities. Rodgers Litho, Tulsa, Oklahoma.

Smeyan, N. I., Lisitsa, V. A. \& Sergeenko, V. T. 2000. Soil formation on sandy and loess-like zebra-layered deposits in Belarus. Pochvovedenie (Eurasian Soil Sci.), 7, 800-807.

Stützer, A. 1998. Early stages of podzolization in young aeolian sediments, Western Jutland. Catena, 32, 115-129.

Targulian, V. O., Sokolova, T. A., Birina, A. G., Kulikov, A. V. \& Tselishcheva, L. K. 1974. Arrangement, Composition and Genesis of Sod-Pale-Podzolic Soil Derived from Mantle Loams. Analytical Investigation. Xth Internat. Congress of Soil Science. Moscow.

Thomson, P. W. 1929. Die regionale Entwicklungsgeschichte der Wälder Estlands. Acta Comment. Univ. Tartuensis, XVII, 88.

van Breemen, N. \& Buurman, P. 1998. Soil Formation. Kluwer Acad. Publ., Dordrecht.

van Ranst, E., Verloo, M., Demeyer, A. \& Pauwels, J. M. 1999. Manual for the Soil Chemistry and Fertility Laboratory. Analytical Methods for Soils and Plants, Equipment and Management of Consumables. Univ. Ghent, Gent, Belgium.

\section{GLEIMULLAL LASUVATE EOOLSETE LIIVADE LEETUMINE EDELA-EESTIS ÜHEKSA TUHANDE AASTA JOOKSUL}

\section{Loit REINTAM, Anto RAUKAS, Anne KLEESMENT, Tanel MOORA ja Raja KÄHRIK}

Lemmejõe kaldapaljandil ( $57^{\circ} 58^{\prime}$ põhjalaiust, $24^{\circ} 25^{\prime}$ idapikkust) uuriti karbonaatsel moreenil kujunenud turvastunud gleimullal lasuvat, eoolsel liival tekkinud huumus-illuviaalset leetunud mulda. Turvastunud gleimuld oli $342-380 \mathrm{~cm}$ sügavusel moodustunud 1500-3200 aasta jooksul enne mattumist Antsülusjärve liiva alla. Orgaanilist süsinikku kogunes keskmiselt $2,5 \mathrm{~g} \mathrm{~m}^{-2} \mathrm{a}^{-1}$ seal, kus mulla- 
teke algas juba jääjärve ajal, ning $5,3 \mathrm{~g} \mathrm{~m}^{-2} \mathrm{a}^{-1}$ seal, kus moreen vabanes jääjärve alt hiljem, kuid setteid sellele ei kogunenud. Turvastunud horisont kujunes ligikaudu 1000 aasta jooksul orgaanilise süsiniku keskmise aastajuurdekasvuga $12-13 \mathrm{~g} \mathrm{~m}^{-2}$. Moreeni gleistumine on põhjustanud tähtsusetuid lõimisemuutusi, kuid esile kutsunud olulisi muutusi selle mineraalses ja keemilises seisundis. Turvastunud gleimuld mattus Antsülusjärve liiva alla 9200-9000 aastat tagasi. Rannalähedased tuuled puhusid kihitatud järveliivade ülemise osa ümber. Selliselt tekkinud eoolsetel liivadel algas üheaegselt metsade arenguga umbes 9000 aastat tagasi mullatekkeprotsess, mille tulemusel kujunes ühtne A-E-Bhs-Bs-BC-C profiiliga huumus-illuviaalne leetunud muld. Orgaanilist süsinikku kogunes A-E-Bhs horisontidesse keskmiselt $8,1 \mathrm{mg} \mathrm{m}^{-2} \mathrm{a}^{-1} \mathrm{~cm}^{-1} . \mathrm{R}_{2} \mathrm{O}_{3^{-}}$ja/või Ca-fulvaatse huumuse mõjutusel arenes leetumine ning valge leethorisondi aastane süvenemine oli keskmiselt $55 \mu \mathrm{m}$. 9000 aasta jooksul kujunenud $180 \mathrm{~cm}$ paksune mullatüsend on tegelikult $171 \mathrm{~cm}$ paksuse lähteliiva murenemise ja leetumise tulem. Granulomeetriliste fraktsioonide muundumine on kogu mullatüsendis põhjustanud peente osakeste ja keemiliste komponentide kogunemist vastavalt 5,6 ja $2,9 \mathrm{~g} \mathrm{~m}^{-2} \mathrm{a}^{-1}$, ehkki A-E horisondid on samas absoluutselt eluviaalsed. Kvarts ja päevakivid on kogunenud peenliivas. Maakmineraalide hulga suurenemine ja/või eluvio-illuviaalne jaotumus on eelkõige seotud pürokseenide ja amfiboolide murenemisega. Inimmõjutused ja mõned looduslikud protsessid on ajendanud leetunud mulla happesuse vähenemist ning neelamismahutavuse ja küllastusastme suurenemist.

\title{
ОПОДЗОЛИВАНИЕ ЭОЛОВЫХ ПЕСКОВ, ПОДСТИЛАЕМЫХ ГЛЕЕЗЕМНОЙ ФОРМАЦИЕЙ, НА ПРОТЯЖЕНИИ ДЕВЯТИ ТЫСЯЧ ЛЕТ В ЮГО-ЗАПАДНОЙ ЭСТОНИИ
}

\author{
Лойт РЕЙНТАМ, АнТо РАУКАС, Анне КЛЕЭСМЕНТ, \\ Танел МООРА и Рая КЯХРИК
}

Обнажения гумусо-иллювиального подзола на эоловых песках, подстилаемого перегнойно-торфянистой глеевой почвой на карбонатной морене последнего оледенения, изучалось на берегу р. Леммейыги, ЮгоЗападная Эстония $\left(57^{\circ} 58^{\prime}\right.$ с. ш., $24^{\circ} 25^{\prime}$ в. д.). Перегнойно-торфянистая глеевая почва образовалась на глубине $342-380$ см в результате оглеения, одернения и оторфования в позднем дриасе-пребореале в течение 1500 3200 лет со среднегодовым приростом органического углерода в 5,3-2,5 г м². Торфянистый горизонт сформировался в течение около 1000 лет со скоростью $12-13$ г м $^{-2}$ год $^{-1}$ органического углерода. Оглеение подстилающей морены вызвало изменения в гланулометрическом, минеральном и химическом составах. 
Перегнойно-торфянистая глеевая почва покрывалась отложениями анциловой трансгрессии примерно 9200-9000 лет назад. После отступания береговой линии поверхностные слоистые анциловые пески передувались прибрежными ветрами в дюны. Почвообразование началось одновременно с развитием лесной вегетации около 9000 лет назад, при этом образовался единый гумусо-иллювиальный подзол A-E-Bhs-Bs-BC-C-профиля. Органический углерод накапливался со средней скоростью 8,1 мг м $^{-2}$ год $\mathrm{cm}^{-1}$ в A-E-Bhs-профиле, причем горизонты А и Bhs оказались, соответственно, гумусо-аккумулятивным и гумусо-иллювиальным. Под влиянием полутораоксидно- и/или кальциево-фульватного гумуса происходило непрерывное оподзоливание и формирование альбикого горизонта со скоростью $55 \mu$ м год ${ }^{-1}$. Почвенная толща мощностью в $180 \mathrm{~cm}$, сформировавшаяся в течение 9000 лет, представляла собой результат выветривания и подзолообразования исходной песчаной толщи в $171 \mathrm{~cm}$. Поверхностная 75-сантиметровая толща прирастала со скоростью 6-7 $\mathrm{M} \mathrm{м}^{-2}$ год $^{-1}$. Из-за межфракционных изменений в почвенной толще шло накопление тонких частиц $\left(5,6\right.$ г м ${ }^{-2}$ год $\left.{ }^{-1}\right)$ и химических составляющих $\left(2,9\right.$ г м ${ }^{-2}$ год $\left.{ }^{-1}\right)$, хотя горизонты А-Е отличались полной элювиальностью. Кварц и полевые шпаты сконцентрировались преимущественно в мелком песке. Увеличение количества рудных минералов и/или их элювио-иллювиальное распределение индуцировались выветриванием пироксенов и амфиболов. На фоне общей аккумулятивности несиликатные полутораоксиды и кремний характеризуются подзолистым распределением в профиле подзола. Вследствие антропогенных и некоторых явно природных воздействий уменьшение кислотности и увеличение емкости поглощения и насыщенности основаниями имели место в горизонтах A-E-Bhs гумусо-иллювиального подзола. 